EDUR • Educação em Revista. 2020; 36:e217885

DOI: http://dx.doi.org/10.1590/0102-4698217885

() (1) $\mathrm{https://creativecommons.org/licenses/by/4.0/}$

\title{
ARTIGO \\ AVALIAÇÃO DAS PROPOSTAS DE EDUCAÇÃO AMBIENTAL VOLTADAS ÀS ÁGUAS EM BACIAS HIDROGRÁFICAS NAS BASES DE DADOS EBSCO, DOAJ E SCIELO
}

\author{
MARA ALINI MEIER ${ }^{1}$ \\ ORCID: https://orcid.org/0000-0001-7955-6180 \\ JANE MÁRCIA MAZZARINO² \\ ORCID: https://orcid.org/0000-0002-6051-5116
}

\begin{abstract}
Resumo: $\mathrm{O}$ estudo teve o intuito de verificar as práticas de Educação Ambiental (EA) voltadas às águas de bacia hidrográfica $(\mathrm{BH})$, no contexto americano e europeu. A metodologia empregada foi a revisão sistemática com meta-análise qualitativa. A busca por artigos científicos ocorreu nas bases de dados da SCIELO, DOAJ e EBSCO, procurando por textos publicados entre os anos de 1992 e 2016, advindos da Europa e da América, sendo que foram obtidos 20 artigos científicos com esta ênfase. As características gerais das práticas demonstraram a sua concentração na América, com autores centralizados em um tipo de entidade de origem e área do conhecimento. Existe a concentração em práticas de EA formal direcionadas para os jovens, de modo que os objetivos, os métodos e os resultados obtidos nas práticas de EA encontram-se centrados na compreensão teórica das questões ambientais e as estratégias pedagógicas em atividades tradicionais, contudo, há propostas inovadoras, dinâmicas e interativas nessa área.
\end{abstract}

Palavras-chave: Educação Ambiental, Bacia Hidrográfica, Meta-análise qualitativa.

\section{EVALUATION OF THE PROPOSALS OF ENVIRONMENTAL EDUCATION DIRECTED TO HYDROGRAPHIC BASIN IN THE DATA BASES EBSCO, DOAJ AND SCIELO}

\begin{abstract}
The aim of this study was to verify the Environmental Education (EE) practices directed to waters of hydrographic basins $(\mathrm{BH})$ in the American and European context. The methodology used was the systematic review with qualitative meta-analysis. The search for scientific articles occurred in the databases of SCIELO, DOAJ and EBSCO, which were published between 1992 and 2016 and came from Europe and America. For this purpose, we obtained 20 scientific articles with this emphasis, which have the general characteristics of the practices demonstrated their concentration in America, with authors centralized in one type of entity of origin and area of knowledge. There is a focus on formal EA practices directed at young people. The objectives, methods and results obtained in EE practices are centered on the theoretical understanding of environmental issues and pedagogical strategies in traditional activities, however there are innovative, dynamic and interactive proposals.
\end{abstract}

Key words: Environmental Education, Hydrographic Basin, Qualitative Meta-analysis.

\section{EVALUACIÓN DE LAS PROPUESTAS DE EDUCACIÓN AMBIENTAL CON ÉNFASIS EN LAS CUENCAS HIDROGRÁFICAS EN LOS BANCOS DE DATOS EBSCO, DOAJ Y SCIELO}

\footnotetext{
1 Universidade do Vale do Taquari (UNIVATES). Lajeado, RS, Brasil. <janemazzarino@univates.br>

2 Universidade do Vale do Taquari (UNIVATES). Lajeado, RS, Brasil.<mara.alini@gmail.com>

Educação em Revista|Belo Horizonte|v.36|e217885|2020
} 
Resumen: El estudio tuvo el objetivo de verificar las prácticas de Educación Ambiental (EA) con énfasis en las cuencas hidrográficas $(\mathrm{CH})$ en el contexto americano y europeo. La metodología utilizada fue la revisión sistemática con meta-análisis cualitativa. La búsqueda por artículos científicos ocurrió en las bases de datos SCIELO, DOAJ y EBSCO, buscando por textos publicados entre 1992 y 2016, provenientes de Europa y de América, siendo que se consiguieron 20 artículos con ese énfasis. Las características generales de las prácticas han demostrado su concentración en América con autores centralizados en una clase de entidad de origen y campo de conocimiento. Existe la concentración en prácticas de EA formal direccionadas a los jóvenes, de manera que los objetivos, los métodos y los resultados conseguidos en estas prácticas se encuentran agrupados en la comprensión teórica de las cuestiones ambientales y en las estrategias pedagógicas de actividades tradicionales. Sin embargo, hay propuestas innovadoras, dinámicas e interactivas en este campo.

Palabras-clave: Educación Ambiental, Cuenca Hidrográfica, Meta-análisis cualitativo.

\section{INTRODUÇÃO}

A Educação Ambiental (EA) começa a ser vista como uma estratégia para amenizar a problemática ambiental na década de 1970 (PELICIONI; PHILIPPI JR, 2014). Desde então, diversos encontros internacionais trataram desse tema.

No contexto internacional, um dos encontros mais valiosos para a discussão da EA foi a Rio92. Conforme Gadotti (2000, p. 95, grifo do autor) "a educação ambiental foi um dos temas de maior destaque do Fórum Global da Rio-92, sendo discutida especialmente na Jornada Internacional de Educação Ambiental".

Foi no bojo das reflexões e ações da Rio 92 que os conceitos e práticas de Educação Popular começaram a dialogar com a Educação Ambiental. Algumas produções significativas são demonstrativas deste processo. Uma delas é o Tratado de Educação Ambiental para Sociedades Sustentáveis e Responsabilidade Global produzido participativamente durante um ano e aprovado durante a Jornada Internacional de Educação Ambiental, parte do Fórum de ONGs e Movimentos Sociais, com educadoras e educadores do mundo inteiro presentes na Rio 92 (VIEZZER, 2005, p. 283).

O Tratado de Educação Ambiental para Sociedades Sustentáveis e Responsabilidade Global vislumbra a educação como um movimento de construção contínuo e a Educação Ambiental como uma área voltada para a sustentabilidade equânime, um movimento constante de aprendizagem que está assentado no apreço aos seres vivos. Além disso, essa prática também é vista como uma alternativa para a minimização dos problemas socioambientais provenientes do capitalismo (GAMA; CARVALHO; CARVALHO JÚNIOR, 2012).

Para Gadotti (2000) o Tratado destaca que a EA deve assentar-se sobre um pensamento crítico, a fim de abrir novos caminhos para a sociedade; envolver o contexto individual, bem como o coletivo, a fim de agir tanto local como globalmente; olhar holisticamente a relação sociedade-natureza; almejar o desenvolvimento de valores como a solidariedade, a igualdade, o respeito e a ética entre todos os seres vivos; articular conhecimentos, aptidões, valores, atitudes e ações (GADOTTI, 2000).

No entanto, devemos estar atentos a iniciativas de EA que se propõem a ser emancipatórias, mas que permanecem atreladas ao conservadorismo. Isso porque elas propiciam mutações ilusórias, não alterando concretamente a realidade e, além do mais, criam obstáculos e as mudanças não se efetivam. Dessa maneira, elas geram descontentamento e desmobilizam a sociedade (LIMA, 2002). Nesse tocante,

[...] se a empresa e o estado - ironicamente os principais geradores de riscos ambientais ocupam-se do problema pelo desenvolvimento de organismos de gestão, conselhos, leis, selos e mercadorias verdes, além de 'programas de educação ambiental', só resta ao cidadão despreocupar-se e cuidar de sua vida privada (LIMA, 2002, p.126). 
Além disso, os assuntos a serem tratados em atividades de EA são diversos, desde a proteção da flora, da fauna, da água, do solo, do ar, das mudanças climáticas etc. No entanto, tem-se o interesse, neste trabalho, de saber quais são as atividades promovidas no contexto da EA direcionadas à temática das águas, o que se justifica pela importância singular da água.

Segundo Tundisi, Braga e Rebouças (2006) todas as atividades humanas e os ecossistemas dependem dos recursos hídricos para que possam existir, no entanto, os autores advertem que a sua disponibilidade é desigual no "espaço e no tempo" (p. 739) e suas fontes podem sofrer impactos significativos da ação humana, por isso necessitam de uma gestão que leve em consideração a sua qualiquantidade. Nesse sentido, Silveira (2003) destaca que uma estratégia importante para o engajamento da sociedade na gestão ambiental é a EA.

A educação ambiental apresenta-se como o instrumento suporte de base que deve anteceder e apoiar, durante todo o processo, de forma contínua e permanente, todas as ações de gestão ambiental, incluindo aquelas de gestão dos recursos hídricos, como pressuposto ao seu efetivo sucesso, pois promove envolvimento, gera cumplicidade e desenvolve, em todos os entes de uma determinada comunidade, a co-responsabilidade para com seus destinos ambientais (SILVEIRA, 2003, p.1).

A gestão dos recursos hídricos necessita ser desenvolvida levando em conta a dinâmica da bacia hidrográfica, considerada o recorte patente para essa finalidade (BRASIL, 1997). Também, de acordo com Ruffino e Santos (2002), a inclusão do conceito de bacia hidrográfica (BH) permite articular diversos conhecimentos, gerando uma visão holística sobre os elementos e processos (solo, água, relevo, flora, fauna, interferência humana, entre outros) que atuam e se articulam nesse espaço. Ainda, a EA voltada para às águas, ao incorporar a $\mathrm{BH}$ permite compreender as interações que compõem o espaço e configurar um olhar abrangente sobre a sua situação.

Diante disso, neste artigo têm-se como objetivo verificar as práticas de EA voltadas às águas no âmbito das bacias hidrográficas nos contextos americano e europeu. Para isso faz-se a análise de artigos provenientes das bases de dados SCIELO, DOAJ e EBSCO. O recorte temporal utilizado encontra-se entre o ano de 1992 (devido à importância que a Eco-92 teve para o aprimoramento da EA) e 2016, tendo os continentes americano e europeu foram definidos como espaço de análise (MEIER, MAZZARINO, s/d, a). Esses dois continentes possuem uma atuação expressiva no debate internacional voltado à causa ambiental e à EA como mecanismo para a promoção e proteção do ambiente, bem como dos recursos hídricos (MUÑOZ, 2000; RIBEIRO, 2008; DIAS; MARQUES; DIAS, 2016).

\section{PROCEDIMENTOS METODOLÓGICOS}

A pesquisa está embasada na revisão sistemática e na meta-análise qualitativa. A esse respeito, a revisão sistemática pode ser compreendida como

[...] uma revisão planejada para responder a uma pergunta específica e que utiliza métodos explícitos e sistemáticos para identificar, selecionar e avaliar criticamente os estudos, e para coletar e analisar os dados destes estudos incluídos na revisão. A meta-análise, ou metanálise ou ainda, metaanálise é o método utilizado na revisão sistemática para integrar os resultados dos estudos incluídos (CASTRO, 2001, p.1).

Castro (2001), com base na "Colaboração Cochrane 3 ", destaca que a revisão sistemática deve seguir sete etapas: a) definição da questão norteadora; b) delimitação da fonte e obtenção das pesquisas

3 A Colaboração Cochrane é uma organização filantrópica com registro na Inglaterra (COLABORAÇÃO COCHRANE, 2018a, s/p). Ela é uma "rede global e independente de pesquisadores, profissionais, pacientes, cuidadores e pessoas interessadas em saúde. Os membros da Cochrane -- 37.000 pessoas em mais de 130 países -- trabalham juntos para produzir informação sobre saúde confiável e acessível [...]" (COLABORAÇÃO COCHRANE, 2018a, s/p). Ela tem como finalidade "possibilitar a tomada de decisões em saúde baseadas em evidências através da produção de revisões sistemáticas de alta qualidade, relevantes e acessíveis e de outros resumos de pesquisas em evidências" (COLABORAÇÃO COCHRANE, 2018b, $\mathrm{s} / \mathrm{p}$ ). 
a serem analisadas; c) apreciação das pesquisas; d) indicação das informações relevantes; e) avaliação e exposição das informações; f) explicação das informações; g) aperfeiçoamento da pesquisa.

A meta-análise aqui empregada está voltada à pesquisa qualitativa e, como exposto por Bicudo (2014), resulta em uma síntese interpretativa das pesquisas que compõem essa análise. Rodrigues (2002) também destaca que a meta-análise qualitativa busca:

[...] identificar, através de determinadas categorias, semelhanças e controvérsias numa quantidade de estudos da mesma área de pesquisa. Trata-se, na verdade, de um processo de descrição interpretativa, orientado por determinadas categorias teóricas. O resultado final é uma visão mais acurada do desenvolvimento da área analisada (RODRIGUES, 2002, p. 26).

A coleta dos artigos foi realizada nas bases de dados da EBSCO ${ }^{4}$, DOAJ e SCIELO, no ano de 2017, entre fevereiro e março, utilizando-se como intervalo temporal os anos de 1992 até 2016 (como mencionado anteriormente). Já o espaço de análise foi a América e a Europa, sendo que se restringiu a busca a artigos científicos e os termos empregados na busca, em português e inglês, foram: Educação Ambiental; recurso hídrico; bacia hidrográfica; e água. Eles foram combinados de diferentes modos com o emprego do operador booleano and e poderiam estar em qualquer segmento do texto. Após encontrar os artigos, realizou-se a análise deles e sua classificação, conforme demonstrado na Figura 1 (MEIER, MAZZARINO, s/d, a).

Figura 1 - Procedimento de classificação dos artigos retirados das bases de dados EBSCO, DOAJ e SCIELO.

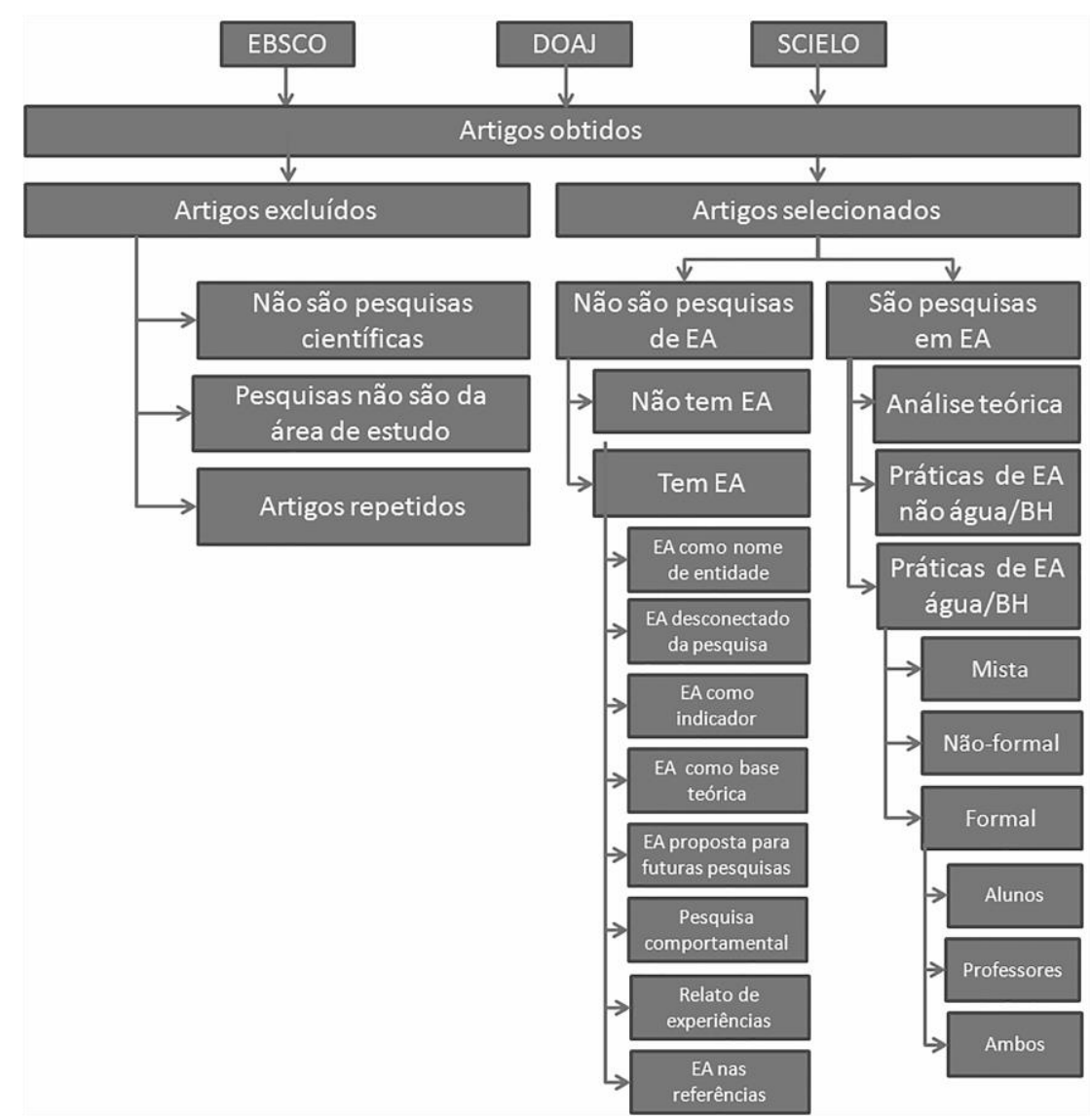

Fonte: Meier e Mazzarino (s/d, a).

Após a pesquisa e a avaliação dos artigos científicos, permaneceram na análise os considerados: pesquisas em EA que apresentam práticas voltadas para as águas em bacias hidrográficas, que foram e classificados conforme as seguintes categorias: 
1. Caracterização da publicação: título; ano de publicação; autores; origem institucional; área de conhecimento; periódico de publicação; e país de origem;

2. Características da pesquisa em análise: caracterização da EA desenvolvida em formal e não-formal; local de desenvolvimento; objetivos; entidade promotora; público-alvo; método e procedimentos adotados; resultados obtidos;

3. Bases teóricas da pesquisa: diretriz teórica que fundamenta a Educação Ambiental identificada a partir da análise das referências bibliográficas mais citadas.

\section{RESULTADOS}

\section{Caracterização da publicação}

Com o desenvolvimento de pesquisa supracitado, embasada em revisão sistemática das bases de dados EBSCO, SCIELO e DOAJ, obteve-se acesso a 51 artigos que abordaram a EA focada nas águas e/ou BH nos contextos americano e europeu. A EBSCO apresentou 20 artigos (39\%), a SCIELO 17 artigos (33\%) e a DOAJ 14 artigos (28\%) (MEIER, MAZZARINO, s/d, a). Dentre os artigos, 20 (39\%) se reportavam à EA dirigida às águas e à $\mathrm{BH}$, sendo que $19(95 \%)$ tratavam de pesquisas práticas e apenas um artigo (5\%) propôs a construção metodológica ${ }^{5}$ de uma atividade prática. Ainda, dentre esses artigos, nove (45\%) são provenientes da SCIELO e $11(55 \%)$ da EBSCO, sendo que a DOAJ não apresentou artigos sobre essa temática. Os demais 31 artigos (61\%) tratavam de práticas de EA referente à proteção das águas, sem incluir na discussão a BH (Figura 2).

Figura 2 - Artigos relacionados à EA voltada às águas de BH.

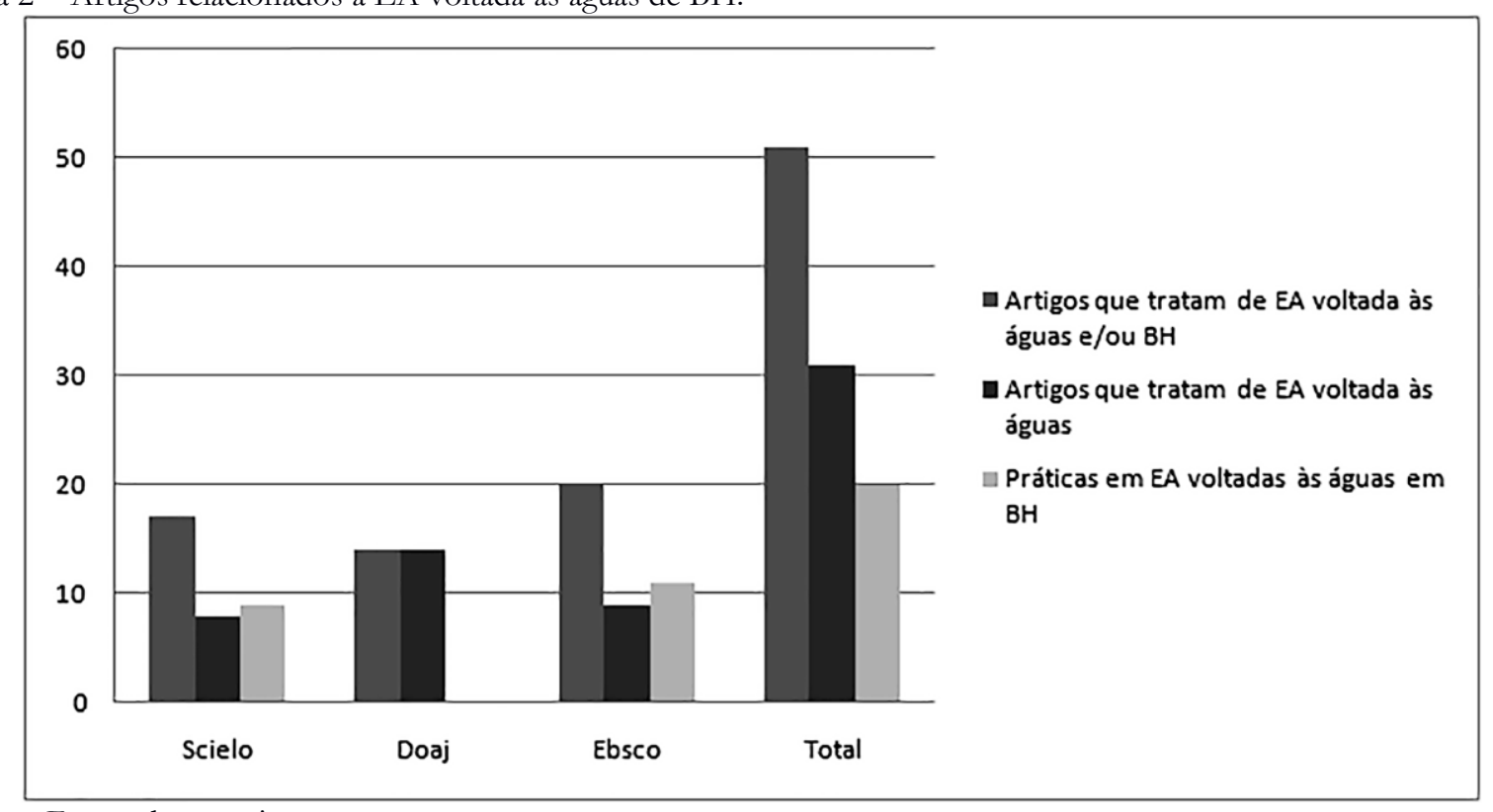

Fonte: da pesquisa.

No quadro 1 e 2, a seguir, são apresentados os artigos cuja temática trata da EA orientada às águas em BH.

$5 \mathrm{O}$ artigo que trata da construção metodológica de uma prática de EA voltada as águas de BH não foi descartado, pois mostrou-se relevante para a discussão da temática, apenas não foi aplicada. 
Quadro 1 - Artigos provenientes da SCIELO avaliados na presente pesquisa

\begin{tabular}{|c|c|c|}
\hline $\mathbf{N}^{\mathbf{0}}$ & Título & Autores \\
\hline \multicolumn{3}{|c|}{ SCIELO } \\
\hline 1 & $\begin{array}{l}\text { Environmental education for sustainable } \\
\text { management of the basins of the rivers } \\
\text { Pirapó, Paranapanema III and Parapanema } \\
\text { IV }\end{array}$ & $\begin{array}{l}\text { Obara, A. T.; Kovalskib, M. L.; Regina, V. B.; } \\
\text { Riva, P. B.; Hidalgob, M. R.; Galvão, C. B.; } \\
\text { Takahashib, B. T. }\end{array}$ \\
\hline 2 & $\begin{array}{l}\text { Educação Ambiental e diálogo de saberes } \\
\text { em região de nascentes do Pantanal: reserva } \\
\text { do Cabaçal, Mato grosso, Brasil }\end{array}$ & $\begin{array}{l}\text { Santos, E. de L. F.; Medeiros, H. Q. de; Silva, C. } \\
\text { J. da. }\end{array}$ \\
\hline 3 & $\begin{array}{l}\text { Explorando a bacia hidrográfica na escola: } \\
\text { contribuições à educação ambiental }\end{array}$ & Bergmann, M.; Pedrozo, C. da S. \\
\hline 4 & $\begin{array}{l}\text { Ui, que nojo! Tem mais é que fechar esse } \\
\text { valetão! Um estudo com o conceito } \\
\text { deleuzeano de devir }\end{array}$ & Palmeiro, V.; Gioppo, C. \\
\hline 5 & $\begin{array}{l}\text { Programa de educación ambiental para } \\
\text { comités de agua potable rural en el sur de } \\
\text { Chile }\end{array}$ & Román, B.; Nahuelhual, L.; Morey , F. \\
\hline 6 & $\begin{array}{l}\text { Rapid Ecological Assessment of benthic } \\
\text { indicators of water quality: a successful } \\
\text { capacity-building experience for Brazilian } \\
\text { postgraduate students in ecology }\end{array}$ & $\begin{array}{l}\text { Callisto, M.; Ribeiro, A. S.; Santana, V. B.; } \\
\text { França, J. S.; Ligeiro, R.; Ferreira, W. R.; Silva, } \\
\text { D.; Castro, D.; Tupinambás, T. H.; Santana, D.; } \\
\text { Souza, B.; Gonçalves, F.; Rodrigues, L.; } \\
\text { Andrade, C. B.; Sales, S. C. M.; Souza, R. }\end{array}$ \\
\hline 7 & $\begin{array}{l}\text { A construção coletiva interdisciplinar em } \\
\text { educação ambiental no ensino médio: a } \\
\text { microbacia hidrográfica do ribeirão dos } \\
\text { peixes como tema gerador }\end{array}$ & Lucatto, L. G.; Talamoni, J. L. B. \\
\hline 8 & $\begin{array}{l}\text { Programa de educación ambiental para la } \\
\text { cuenca del río mucujún: una ventana de } \\
\text { extensión universitaria }\end{array}$ & Molina, Y. \\
\hline 9 & $\begin{array}{l}\text { A Educação Ambiental como estratégia de } \\
\text { mobilização social para o enfrentamento da } \\
\text { escassez de água }^{6}\end{array}$ & $\begin{array}{l}\text { Piccoli, A. de S.; Kligerman, D. C.; Cohen, S. C.; } \\
\text { Assumpção, R. F. }\end{array}$ \\
\hline
\end{tabular}

Fonte: da pesquisa.

Quadro 2 - Artigos advindos da EBSCO avaliados na presente pesquisa

\begin{tabular}{|c|l|l|}
\hline $\mathbf{N}^{\circ}$ & \multicolumn{1}{|c|}{ Título } & \multicolumn{1}{|c|}{ Eutores } \\
\hline \multicolumn{1}{|c|}{10} & $\begin{array}{l}\text { Developing Great Lakes Literacy and } \\
\text { Stewardship through a Nonformal Science } \\
\text { Education Camp }\end{array}$ & Dann, S. L.; Schroeder, B. \\
\hline 11 & $\begin{array}{l}\text { Communicating How Water Works: Results } \\
\text { From a Community Water Education } \\
\text { Program Cockerill, K. }\end{array}$ & Con \\
\hline 12 & $\begin{array}{l}\text { A Drainage Basin in Environmental and } \\
\text { Geographical Education: A Case Study of } \\
\text { the Kretinka Drainage Basin }\end{array}$ & Petrikova, G. \\
\hline
\end{tabular}

6 Este artigo trata de uma proposta de construção metodológico sobre uma atividade prática na área de EA voltada às águas de $\mathrm{BH}$. 


\begin{tabular}{|c|c|c|}
\hline 13 & $\begin{array}{l}\text { Integrating Instructional Technologies in a } \\
\text { Local Watershed Investigation With Urban } \\
\text { Elementary Learners }\end{array}$ & Bodzin, A. M. \\
\hline 14 & $\begin{array}{l}\text { Learning through participatory resource } \\
\text { management programs: case studies from } \\
\text { Costa Rica }\end{array}$ & Sims, L.; Sinclair, A. J. \\
\hline 15 & $\begin{array}{l}\text { Linking Theory to Practice: A Case Study } \\
\text { of Pupils' Course Work on Freshwater } \\
\text { Pollution }\end{array}$ & Österlind, K.; Halldén, O. \\
\hline 16 & $\begin{array}{l}\text { Reflections on an Environmental } \\
\text { Education Summer Program in A } \\
\text { ppalachian Ohio }\end{array}$ & Watson, S. A. \\
\hline 17 & $\begin{array}{l}\text { The Impact of a Place-Based Professional } \\
\text { Development Program on Teachers' } \\
\text { Confidence, Attitudes, and Classroom } \\
\text { Practices }\end{array}$ & Meichtry, Y.; Smith, J. \\
\hline 18 & $\begin{array}{l}\text { The Impact of a Professional Development } \\
\text { Program on Teachers' Understandings } \\
\text { about Watersheds, Water Quality, and } \\
\text { Stream Monitoring }\end{array}$ & $\begin{array}{l}\text { Shepardson, D. P.; Harbor, J.; Cooper, B.; } \\
\text { Mcdonald, J. }\end{array}$ \\
\hline 19 & $\begin{array}{l}\text { Thinking like a fish: curriculum } \\
\text { enhancements for increased environmental } \\
\text { learning in hydraulics and hydrology }\end{array}$ & Hyde, R. A.; Karney, B. W \\
\hline
\end{tabular}

Fonte: da pesquisa.

Os artigos que apresentam pesquisas de EA voltada às águas de $\mathrm{BH}$ encontram-se distribuídos entre os anos de 1999 a 2016, porem a maior quantidade de publicações por ano ocorreu entre 2007 e 2008. Nos demais, a quantidade de publicações foi baixa, mas contínua, não havendo períodos significativos de publicação (Figura 3). Além disso, verificou-se que foram necessários sete anos a partir da Rio-92 para que a primeira publicação fosse feita na área de EA voltada às águas de BH. Isso possivelmente ocorreu devido ao tempo necessário para a transposição e maturação das ideias provenientes desse evento para a área da EA no contexto das BHs.

Figura 3 - Ano de publicação dos artigos relacionados a EA voltada às águas de BH

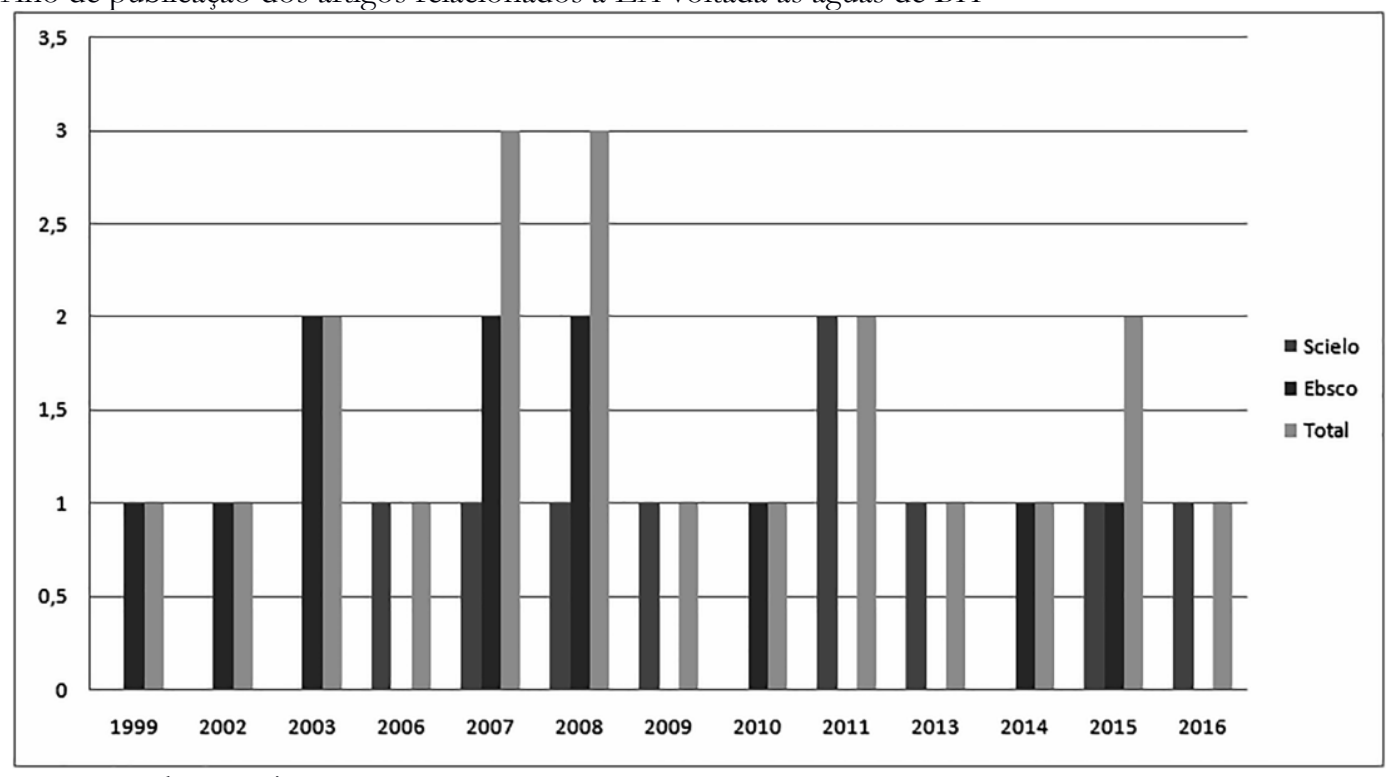

Fonte: da pesquisa. 
Ainda a respeito dos artigos, eles foram publicados em 11 periódicos diferentes, sendo que os da SCIELO são provenientes de cinco periódicos (45\%) e os da EBSCO de seis periódicos distintos $(55 \%)$ (Figura 4). Eles também abrangem diferentes áreas do conhecimento ${ }^{7}$ como: educação; engenharia; Educação Ambiental; biologia; saúde coletiva; geografia e Educação Ambiental; água e educação; multidisciplinar. O destaque fica para a área da educação, com quatro periódicos (36\%) (quadro 3).

Figura 4 - Periódicos de publicação dos artigos relacionados a EA voltada às águas de BH.

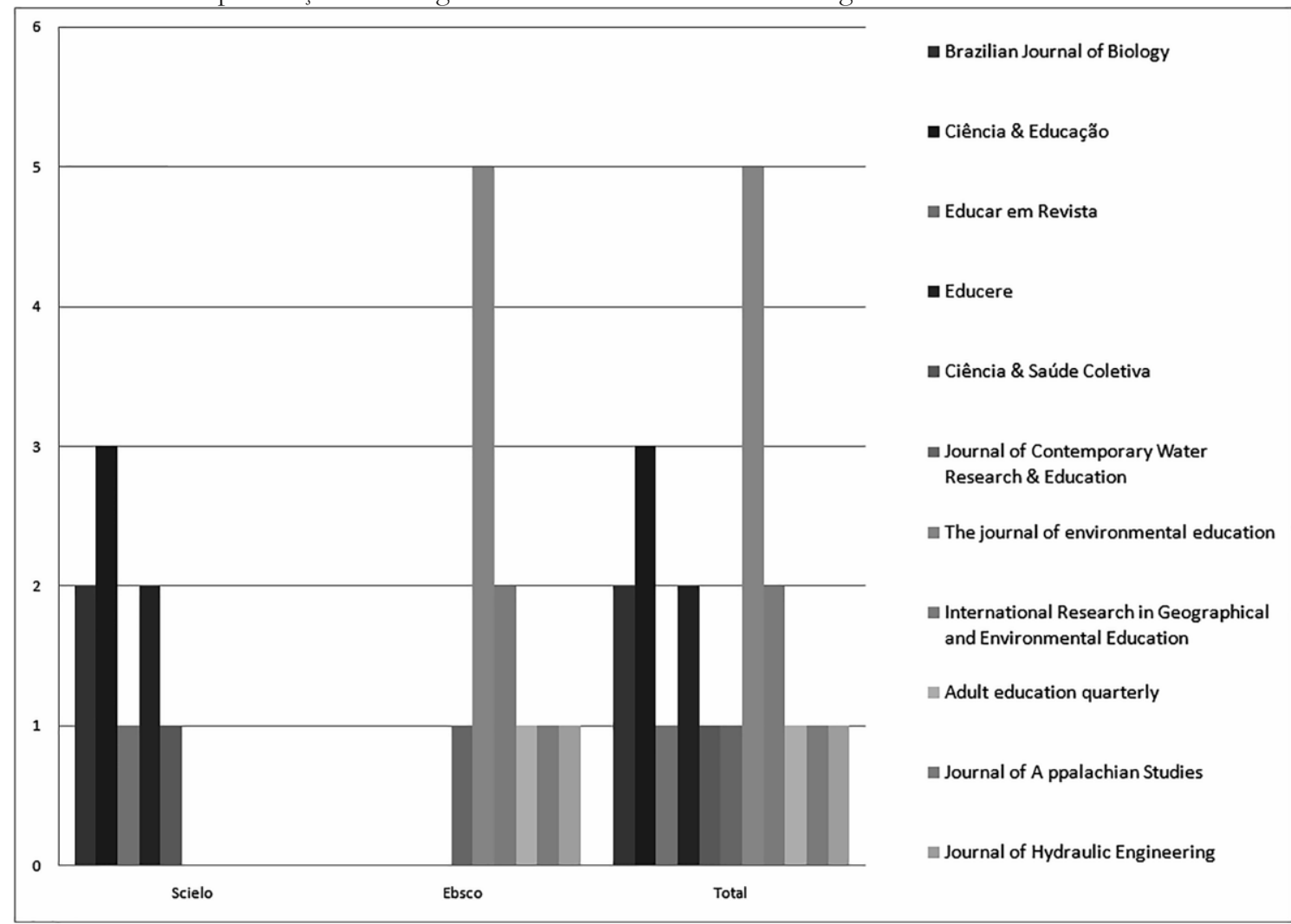

Fonte: da pesquisa.

Esses periódicos se organizam em diferentes áreas do saber, como demonstrado no quadro 3 , que segue a classificação das autoras.

Quadro 3 - Periódico e área do conhecimento em que foram publicados os artigos avaliados

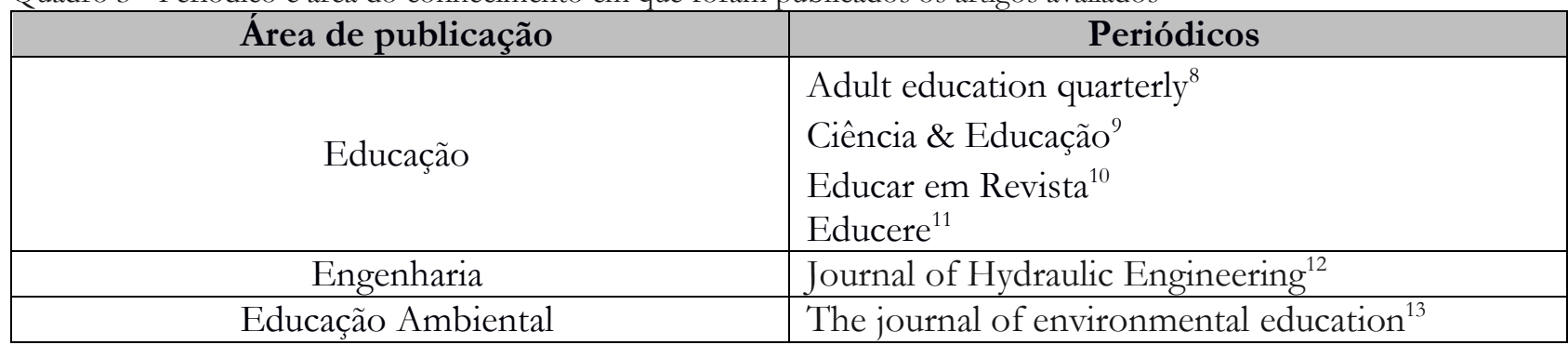

7 As áreas de conhecimento foram definidas pelas autoras a partir da leitura das informações disponíveis nas páginas dos periódicos.

8 Para informações acessar https://us.sagepub.com/en-us/sam/journal/adult-education-quarterly\#description

9 Para informações acessar http://www.fc.unesp.br/\#!/ciedu

10 Para informações acessar http://revistas.ufpr.br/educar

11 Para informações acessar http://www.human.ula.ve/adocente/educere/

12 Para informações acessar https://ascelibrary.org/page/jhend8/editorialboard

13 Para informações acessar

http://www.tandfonline.com/action/journalInformation?show=aimsScope\&journalCode=vjee20

Educação em Revista|Belo Horizonte|v.36|e217885|2020 


\begin{tabular}{|c|l|}
\hline Biologia & Brazilian Journal Of Biology $^{14}$ \\
\hline Saúde coletiva & Ciência \& Saúde Coletiva $^{15}$ \\
\hline Geografia e educação ambiental & $\begin{array}{l}\text { International Research in Geographical and } \\
\text { Environmental Education }^{16}\end{array}$ \\
\hline Água e educação & $\begin{array}{l}\text { Journal of Contemporary Water Research \& } \\
\text { Education }^{17}\end{array}$ \\
\hline Multidisciplinar & Journal of Appalachian Studies $^{18}$ \\
\hline
\end{tabular}

Fonte: da pesquisa.

O periódico que se destacou com cinco artigos publicados (25\%) foi o "The journal of environmental education", sendo que todos os artigos foram provenientes da EBSCO. Esse periódico é internacional e especializado na temática da EA e da sustentabilidade, aceitando artigos de todas as áreas do conhecimento. Ele também publica artigos que abordam a pesquisa no âmbito teórico e prático da EA e que envolvem qualquer nível de ensino, além de EA formal, não formal e informal (THE JOURNAL OF ENVIRONMENTAL EDUCATION, 2018).

O segundo periódico com destaque no número de artigos foi o "Ciência \& Educação" com três artigos (15\%), todos provenientes da plataforma da SCIELO. Esse é um periódico brasileiro, sustentado pela Universidade Estadual Paulista (UNESP). Ele publica artigos voltados à educação e à aprendizagem na área de ciências e matemática (CIÊNCIA \& EDUCAÇÃO, 2018), não sendo específico da temática de EA.

Verificou-se, também, que a publicação de pesquisas na área de EA voltada às águas de BH estão presentes em diferentes periódicos que abrangem múltiplas áreas do conhecimento. Isso bastante é relevante para o desenvolvimento das práticas nessa área da EA, pois elas são permeadas por diferentes olhares, o que auxilia na estruturação de propostas ricas e variadas e um aprimoramento contínuo sob diferentes perspectivas.

Ainda, os artigos foram resultantes dos continentes americano (América do Sul e do Norte) - 18 artigos $(90 \%)$ - e europeu - com dois artigos (10\%). Os países em que houve o maior número de publicações pertencem à América: Estados Unidos da América, com sete artigos (35\%); Brasil, com sete artigos (35\%). Juntos, os dois países somam $70 \%$ das publicações na área de EA voltada às águas de $\mathrm{BH}$ (Figura 5).

Figura 5 - País de origem dos artigos relacionados a EA voltada às águas de BH.

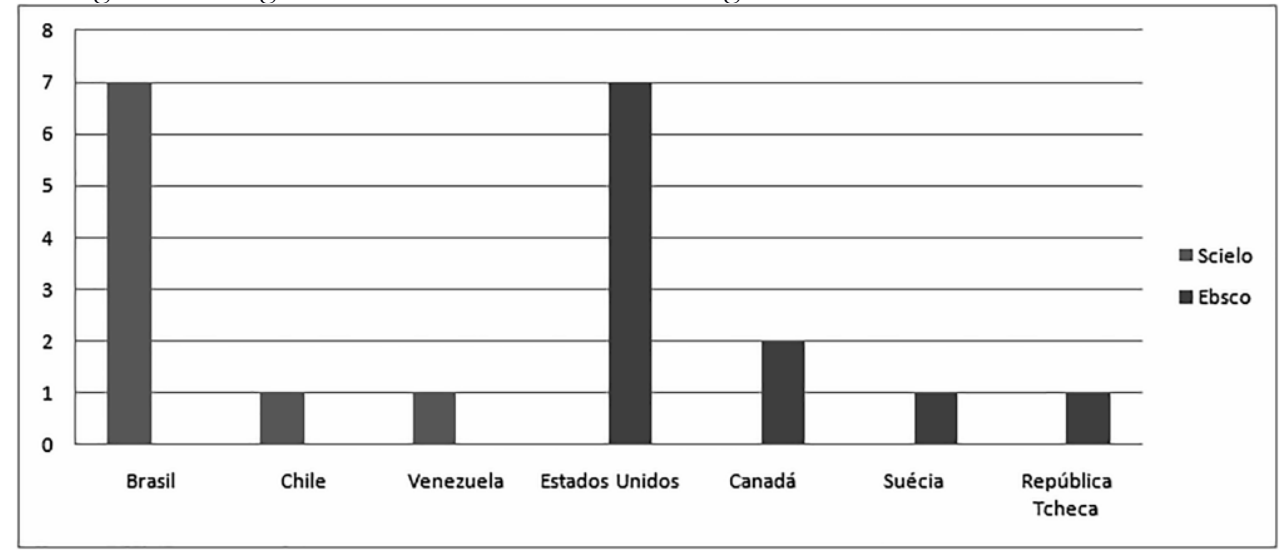

Fonte: da pesquisa.

14 Para informações acessar http://bjb.com.br/

15 Para informações acessar http://www.cienciaesaudecoletiva.com.br/sobre-a-revista

16 Para informações acessar

http://www.tandfonline.com/action/journalInformation?show=aimsScope\&journalCode=rgee20

17 Para informações acessar http://ucowr.org/uncategorised/about-jcwre

18 Para informações acessar http://appalachianstudies.org/journal/

Educação em Revista|Belo Horizonte|v.36|e217885|2020 
Já os artigos da SCIELO foram provenientes dos países da América do Sul, com destaque para o Brasil, enquanto os da EBSCO são originários da América do Norte e da Europa, com preponderância dos Estados Unidos da América (EUA).

Diante do exposto, percebe-se que existe um protagonismo dos países da América com dois núcleos visíveis: um na América do Norte (EUA) e outro na América do Sul (Brasil), tanto na área de desenvolvimento de práticas, quanto de publicação no âmbito da temática da EA voltada às águas de BH. A Europa, no entanto, possui uma atuação ínfima nessa temática e as causas para isso merecem um aprofundamento em estudos ainda a ser realizados.

Essa situação demonstra o interesse, nesses países, com o aprimoramento da EA voltada às águas de BH. Nessa direção, é possível perceber a estruturação de uma comunidade científica norte americana e brasileira atentas às problemáticas que permeiam os recursos hídricos e que buscam construir um olhar integrado sobre as diferentes realidades das suas BHs, o que, por sua vez, poderá auxiliar na resolução de problemas relacionados a elas de forma eficiente e incisiva, levando em conta as dinâmicas das $\mathrm{BH}$.

Nenhum artigo apresentou autores em comum, o que permite verificar que uma quantidade variada de pesquisadores se encontra envolvida em práticas na área de EA direcionada às águas de $\mathrm{BHs}$, mas aponta-se a tendência de os artigos abordarem questões pontuais sobre o tema. No total são 59 autores, sendo que $40(68 \%)$ fazem parte dos artigos advindos da SCIELO e 19 (32\%) são provenientes dos artigos da EBSCO.

Com relação aos autores, que totalizam 51 (86\%), a maioria atua em universidades. Alguns são vinculados a outras entidades de ensino e a órgãos públicos, cada um com quatro (7\%) autores. Nesse contexto, todos os autores dos artigos advindos da EBSCO são vinculados a universidades, ao passo que os dos artigos provenientes da SCIELO têm universidades como origem institucional, somando 32 $(80 \%)$, sendo que pertencentes a outras entidades de ensino são quatro $(10 \%)$ e a órgãos públicos quatro $(10 \%)$ autores (Figura 6).

Figura 6 - Origem institucional dos autores dos artigos relacionados à EA voltada às águas de $\mathrm{BH}$.

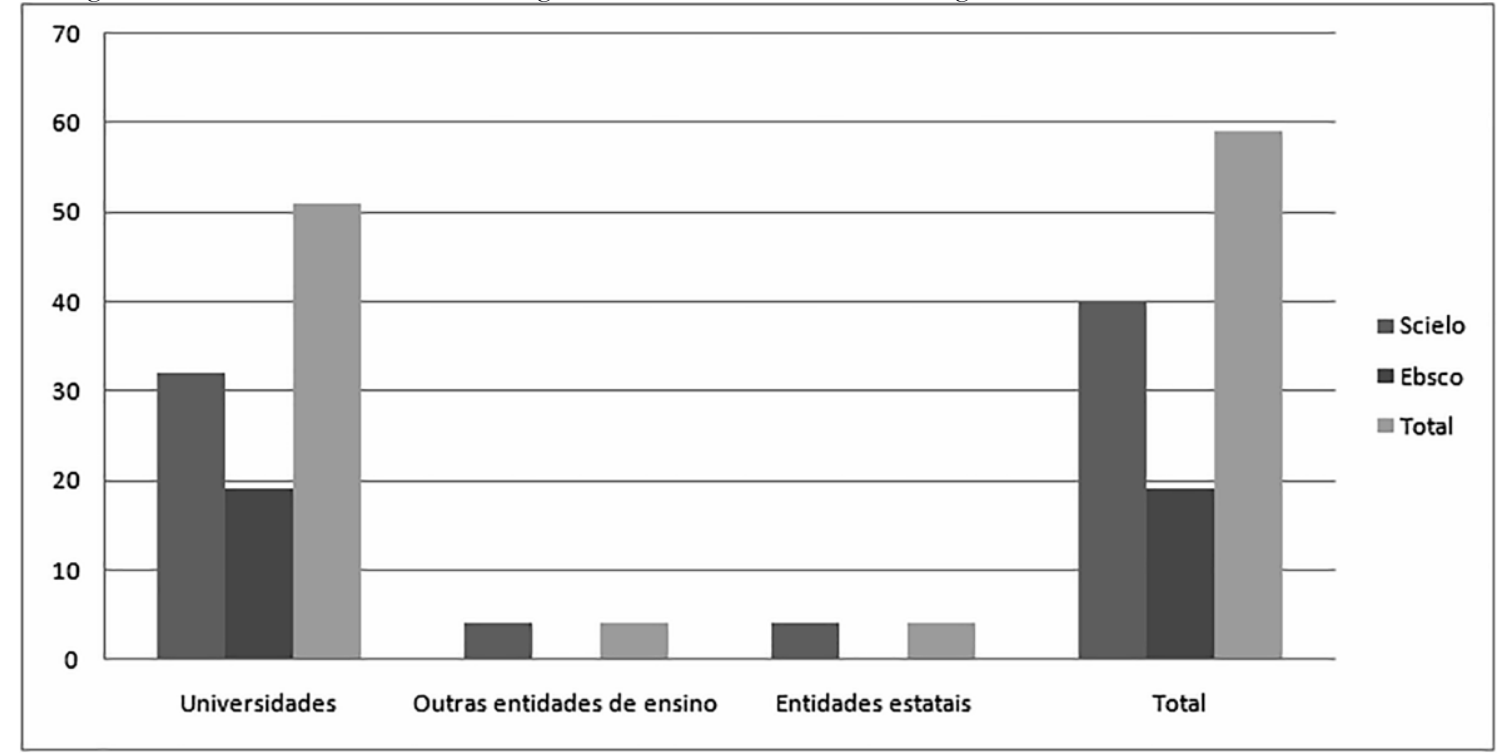

Fonte: da pesquisa.

Diante disso, percebe-se que as universidades são os órgãos que apresentam domínio sobre as práticas de EA voltadas às águas de $\mathrm{BH}$, existindo pouca atuação de outras entidades, o que também está atrelado ao escopo dos periódicos. Esse aspecto permite reconhecer que são as instituições de ensino que fomentam e impulsionam a EA nessas bases, o que explica também porque são elas que possuem recursos humanos qualificados para este tipo de produção. No entanto, as demais instituições devem estar presentes nesse processo para que as propostas de EA sejam construídas por uma gama 
diversificada de atores sociais, contribuindo para práticas variadas e que agreguem diferentes perspectivas e saberes não só científicos.

Dentre os artigos, verificou-se que 17 (85\%) possuem um conjunto de autores com uma origem institucional única e três $(15 \%)$ são compostos por um conjunto de autores de origem institucional mista (Figura 7).

Figura 7 - Conjunto dos autores dos artigos relacionados a EA voltada às águas de BH e sua origem institucional: única e mista.

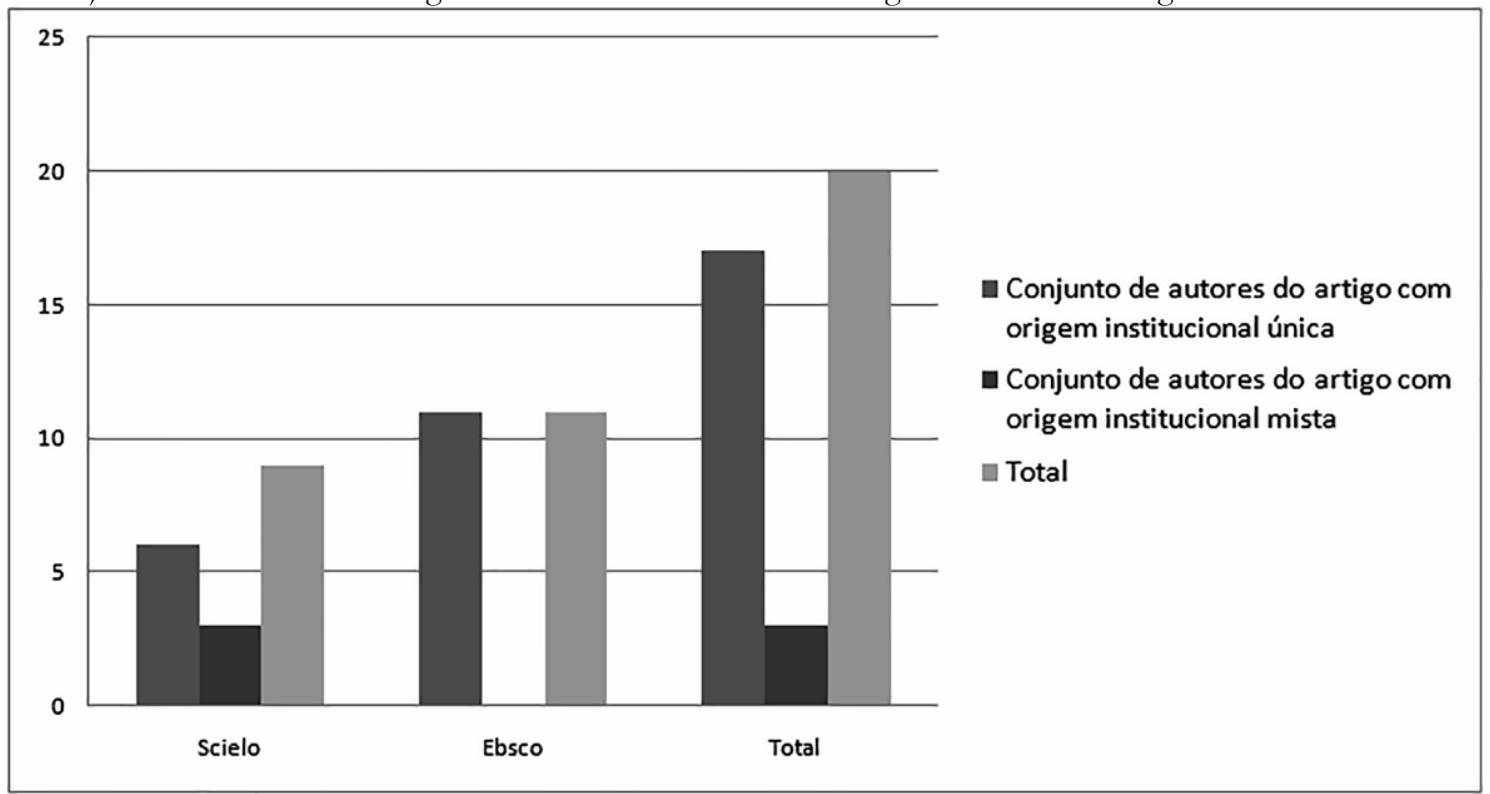

Fonte: da pesquisa.

Além disso, são $16(80 \%)$ os artigos que possuem o conjunto de autores de origem única relacionados a universidades, sendo que apenas um deles (5\%) atrela-se a outra entidade de ensino. Os textos que possuem o conjunto de seus autores de origem mista agregaram: universidades distintas, com um artigo (5\%); órgão público e universidade, com um artigo (5\%); universidades distintas e órgão público, com um artigo (5\%) (Figura 8 ).

Figura 8 - Conjunto dos autores dos artigos relacionados a EA voltada às águas de $\mathrm{BH}$ e sua origem institucional: tipo de entidade.

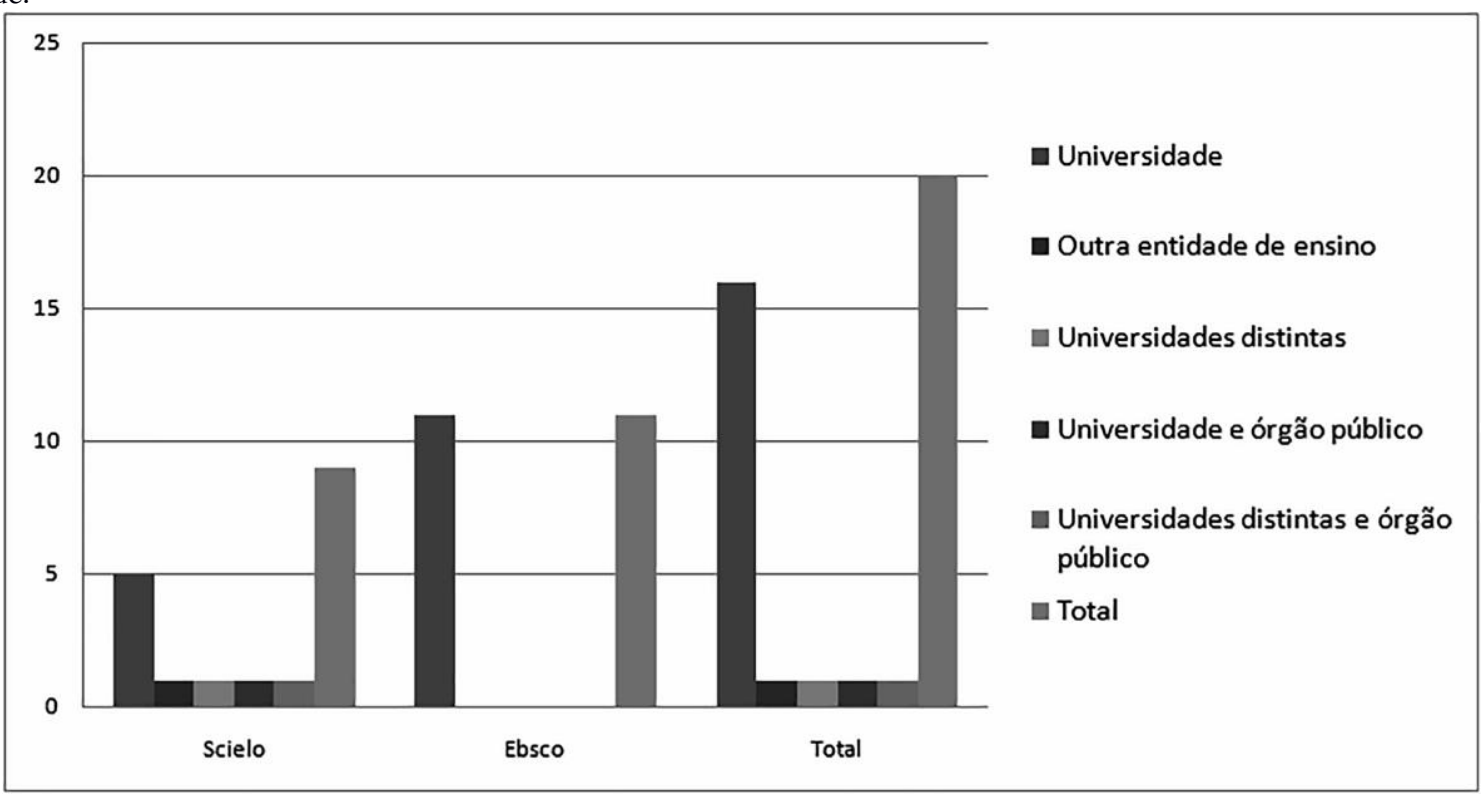

Fonte: da pesquisa. 
Frente ao exposto verifica-se que as universidades dominam a área de pesquisa de EA voltada às águas de $\mathrm{BH}$. Soma-se $\mathrm{a}$ isso o fato de que as universidades possuem uma articulação restrita com outras entidades, o que demonstra a falta de interlocução também com outros atores. Portanto, é importante que diferentes entidades estejam engajadas na EA e integradas entre si, a fim de que essas experiências sejam cada vez mais abrangentes e variadas e, além disso, possam articular diferentes perspectivas em moldes interdisciplinares.

Nesse sentido, todos os artigos provenientes da EBSCO apresentaram o conjunto dos seus autores com origem institucional única, ou seja, provenientes da mesma universidade. Assim, percebe-se que existe pouca cooperação entre diferentes entidades no desenvolvimento dessas pesquisas. Já os artigos advindos da SCIELO apresentaram um conjunto de seus autores oriundos de uma instituição única em seis artigos (67\%) e de origem institucional mista em três textos (33\%). Isso demonstra a existência de articulação, mesmo que pequena, entre diferentes entidades no desenvolvimento das pesquisas, o que é um aspecto positivo, pois permite a experiência de pesquisa em EA voltada às águas de $\mathrm{BH}$ de forma mais diversificada, abrangente e decorrente de processos de cooperação.

As áreas do conhecimento às quais estão vinculados os autores dos artigos é bastante variada. Se classificarmos os autores conforme define o CNPQ (2018) temos como áreas de maior destaque as ciências biológicas com 22 autores (37\%) e a área das ciências humanas com 12 autores (20\%). Na área das ciências biológicas, estão presentes pesquisadores focados em biologia, biodiversidade e ecologia, enquanto que na área das ciências humanas encontram-se autores que estão envolvidos com a educação, educação ambiental e psicologia.

Nesse contexto, os autores de artigos provenientes da SCIELO, vinculados às ciências biológicas, totalizaram 22 (55\%); já os autores da EBSCO, que em sua maioria não especificaram a área a que pertencem, totalizaram sete $(37 \%)$ e, entre os que especificaram, obteve destaque a área de ciências humanas com cinco autores (26\%) (Figura 9). Os dados apontam ainda uma proeminência de autores das Ciências Exatas e da Terra e Biológica nos estudos sobre EA em bacias hidrográficas no contexto pesquisado, mas mesmo assim, é relevante a produção em Ciências Humanas e Sociais Aplicadas.

Figura 9 - Área do conhecimento dos autores dos artigos relacionados a EA voltada às águas de BH.

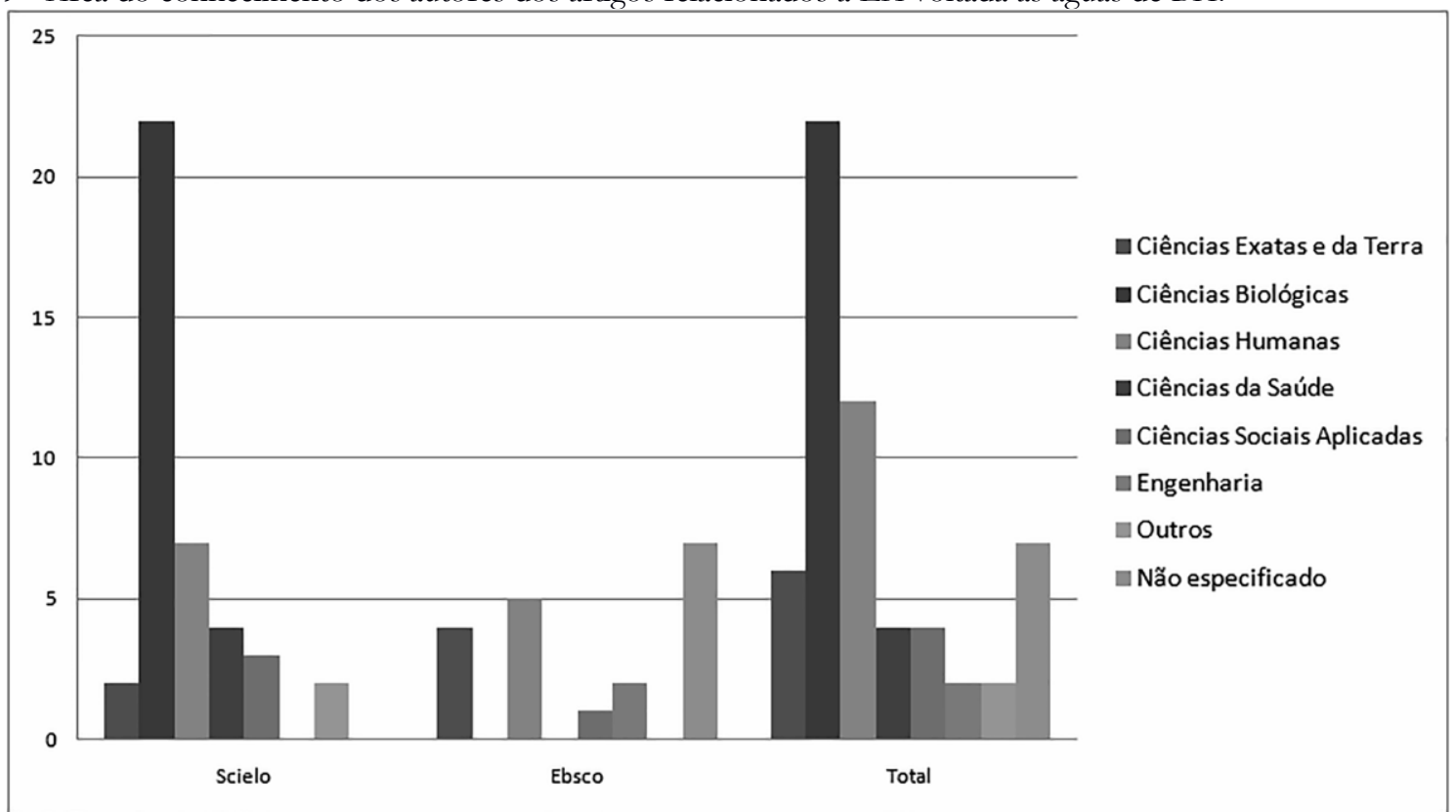

Fonte: da pesquisa.

O conjunto de autores dos artigos possui, em sua maior parte, participantes da mesma área do conhecimento (CNPQ, 2018) - 13 artigos (65\%) -, sendo que poucos artigos possuem uma gama de autores provenientes de áreas distintas do conhecimento - apenas três artigos (15\%). O maior número 
de artigos do SCIELO e da EBSCO, porém, é o que reúne autores da mesma área do conhecimento sete do SCIELO (78\%) e seis artigos da EBSCO (54\%) (Figura 10).

Esse aspecto apresenta limitações na construção das propostas de EA voltadas às águas de $\mathrm{BH}$, pois os autores são, em sua maioria, provenientes de apenas uma área do conhecimento. E, como vimos, é necessária a articulação entre as diferentes áreas para que se possam estruturar pesquisas diversificadas e moldá-las sob diferentes interpretações da problemática ambiental, em especial a sugerida no título deste artigo, isto é, as pesquisas de EA em bacias hidrográficas nos contextos americano e europeu carecem de um olhar interdisciplinar.

Figura 10 - Área do conhecimento do conjunto de autores dos artigos relacionados à EA voltada às águas de $\mathrm{BH}$.

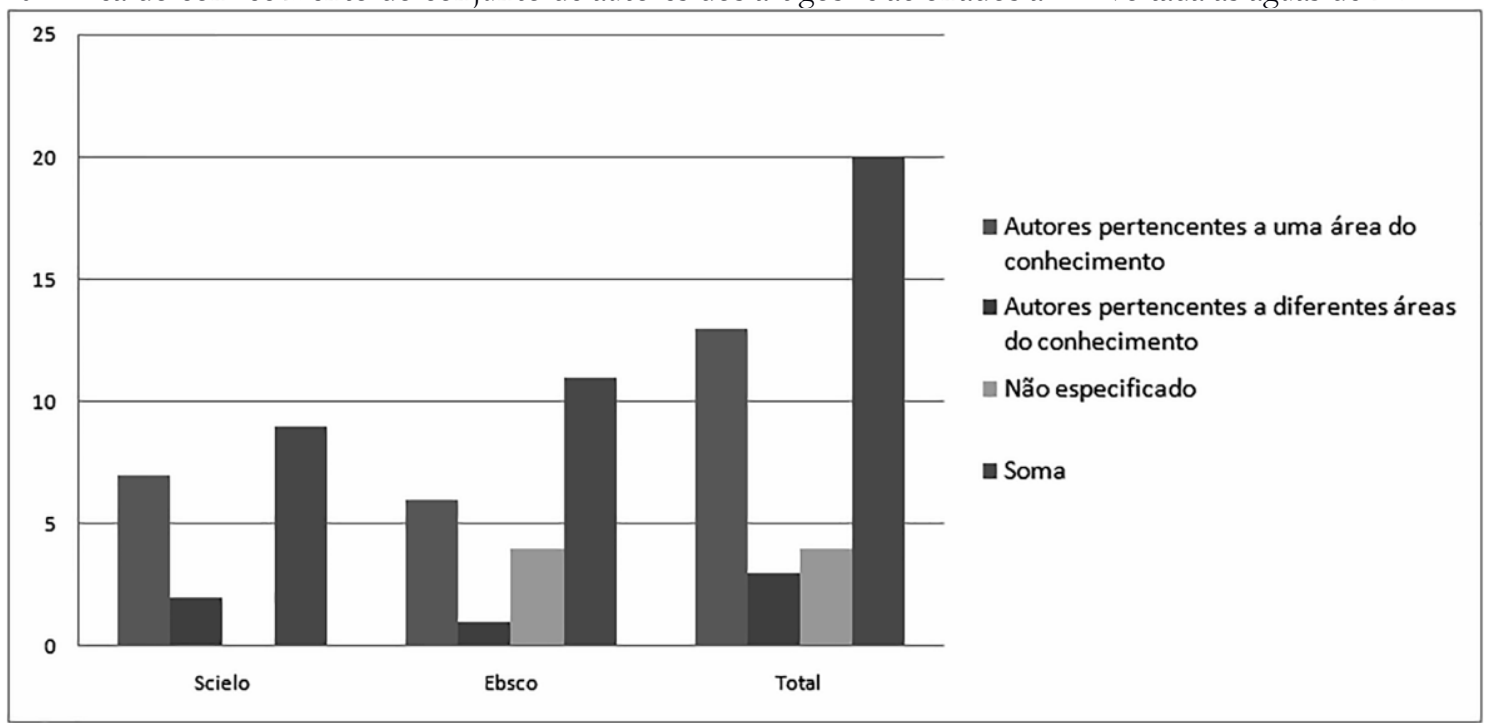

Fonte: da pesquisa.

Cabe ressaltar, ainda, que a pesquisa nas bases de dados se deu mediante a busca de termos em qualquer local do texto e não apenas no título, resumo ou palavras-chave (MEIER, MAZZARINO, s/d, a). Essa foi uma escolha acertada, pois $14(70 \%)$ artigos apresentavam todos os termos de busca apenas no corpo do texto. Diante disso, percebe-se que, se a busca tivesse sido restrita ao título, ao resumo ou às palavras-chave, não teria sido possível analisar uma soma significativa de artigos que tratam da EA voltada às águas de $\mathrm{BH}$.

\section{Características das pesquisas em análise}

As pesquisas foram aplicadas nos continentes americano (Brasil, Chile, Venezuela, Costa Rica, Estados Unidos da América e Canadá) e europeu (República Tcheca). Os países que se destacaram foram os Estados Unidos da América, com sete estudos (35\%), que foram provenientes de artigos da EBSCO, e o Brasil, com seis pesquisas (30\%) advindas de artigos da SCIELO. Das avaliadas, 17 (85\%) foram desenvolvidas por autores em seus respectivos países, sendo que apenas uma pesquisa (5\%), a de Sims e Sinclair (2008), foi realizada na Costa Rica, mesmo os autores sendo canadenses. Somente uma prática (5\%) não especificou o local onde foi implementada e uma outra $(5 \%)$ refere-se a uma construção metodológica, não tendo sido aplicada (Figura 11).

Nesse viés, as pesquisas foram postas em prática por diversas entidades, mas as universidades tiveram destaque, pois desenvolveram nove delas (45\%). Dentre os trabalhos, $13(65 \%)$ foram feitos por apenas uma entidade, enquanto que seis (30\%) tiveram um grupo misto de envolvidos (Figura 12). Os grupos mistos foram compostos por uma universidade e outras entidades de ensino (escolas de ensino básico), com quatro pesquisas (66\%); universidade, órgão público, ONG, organização da sociedade civil, com uma pesquisa (17\%); e universidade, organização sem fins lucrativos e escritório de extensão com uma pesquisa (17\%). Ademais, os trabalhos provenientes dos artigos da SCIELO foram promovidos, em sua maioria, por universidades somando seis artigos (67\%), enquanto que os trabalhos dos artigos da 
EBSCO tiveram, em sua maioria, autoria mista com quatro autores $(36 \%)$ por universidades com três propostas $(27 \%)$.

Figura 11 - Local de aplicação do estudo empírico.

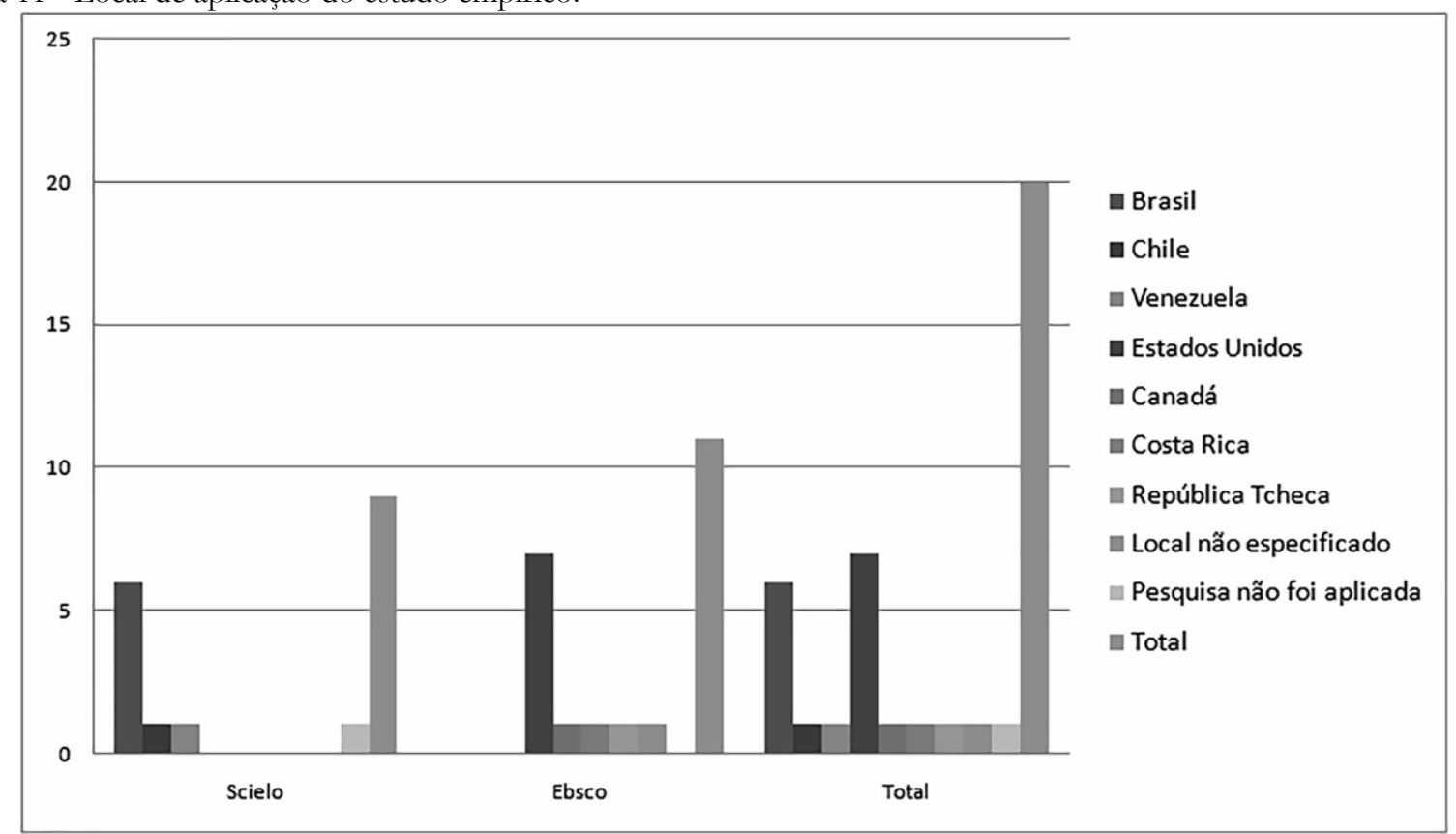

Fonte: da pesquisa.

Figura 12 - Entidade promotora da pesquisa.

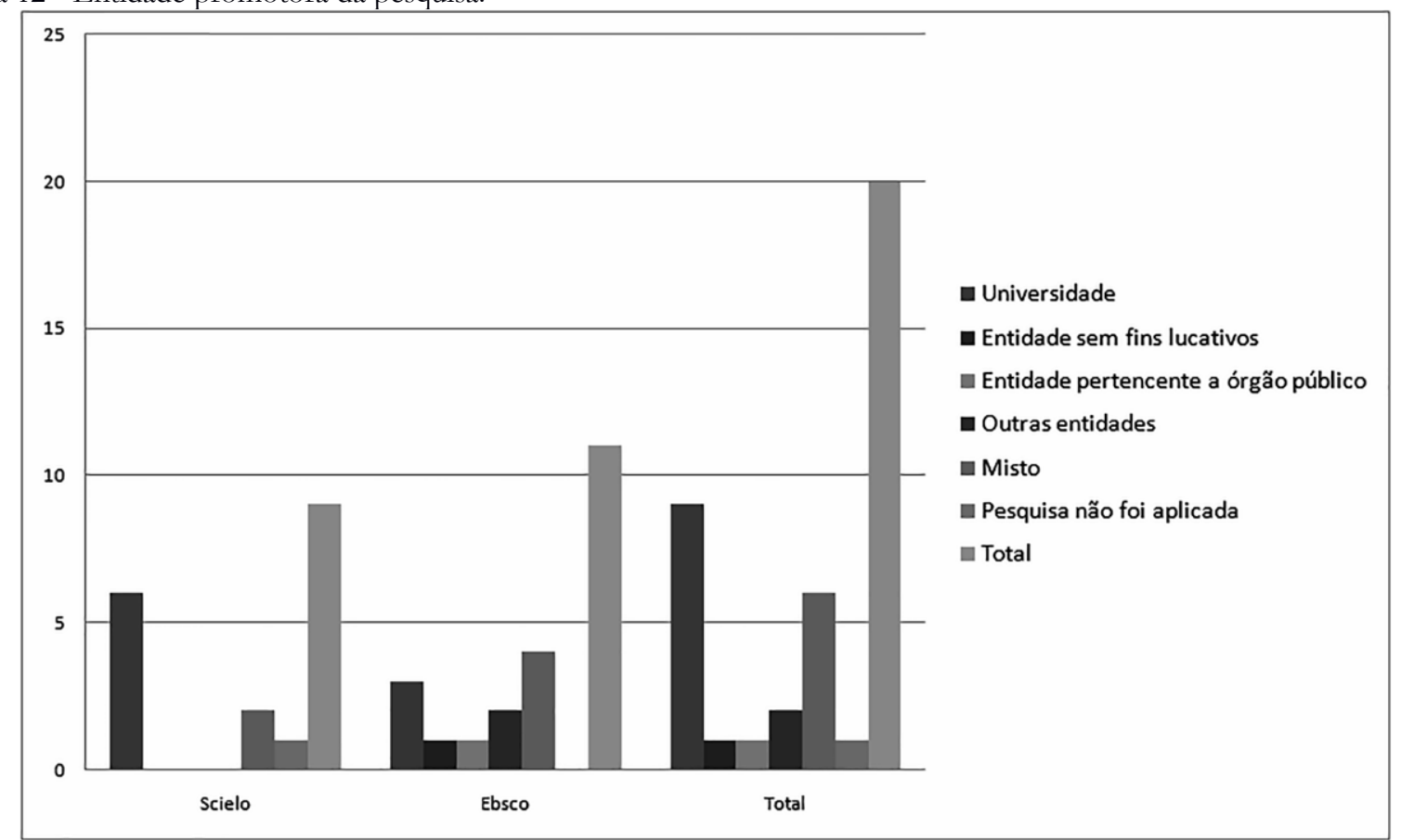

Fonte: da pesquisa.

As práticas de $\mathrm{EA}$ voltadas às águas de $\mathrm{BH}$ tratam de atividades formais com 12 práticas (60\%), não-formais com sete (35\%) e mistas com uma (5\%) (Figura 13). Verifica-se, assim, que a EA voltada à temática das águas de $\mathrm{BH}$ encontra-se centrada no âmbito escolar e pouco vem sendo desenvolvida no contexto mais amplo da sociedade. Por um lado, são as escolas que formam os cidadãos desde sua infância, sendo significativo o seu engajamento nas práticas de EA, no entanto, é necessário pensar na continuidade desse trabalho no âmbito da sociedade e de sua atuação frente às diversas 
problemáticas locais, sendo imprescindível para a constituição de uma sociedade sustentável. Ainda, observou-se que pouco se tem feito no desenvolvimento de atividades que possam articular a EA formal e não-formal, o que é algo relevante, pois contribui para a constituição de

[...] um círculo virtuoso formado pela aprendizagem escolar e social desenvolvida nas comunidades. A preocupação com os problemas ambientais locais ajuda a criar esse novo espaço de relações que, sem excluir a escola, a expande e constitui a comunidade como um novo ator nessa dinâmica, estabelecendo novos vínculos de solidariedade. Trata-se, enfim, de gerar novas reciprocidades entre a escola, a comunidade e a realidade socioambiental que as envolve (CARVALHO, 2008, p.158).

Figura 13 - Classificação das práticas de EA voltada à BH e às águas.

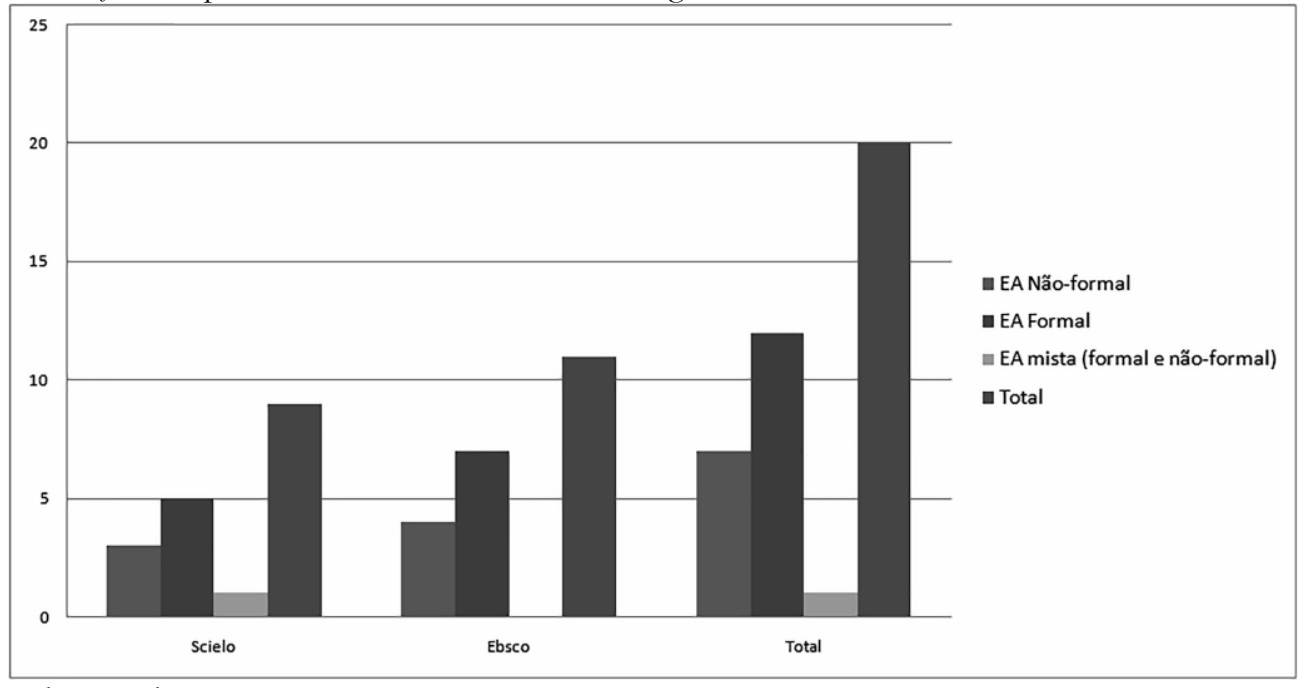

Fonte: da pesquisa.

As experiências de EA envolveram diferentes públicos: grupos sociais diversos (comunidades, agricultores, técnicos ambientais, pesquisadores, representantes de comitês de água, entre outros) em sete práticas de EA (28\%); professores também em sete delas $(28 \%)$ e alunos ou crianças e jovens em 11 dessas práticas (44\%) (Figura 14). Dessa forma, é possível averiguar que, majoritariamente, são as pessoas mais jovens o alvo das atividades de $\mathrm{EA}$ voltadas às águas de $\mathrm{BH}$, uma vez que esse é um público que se encontra em formação e que poderá ser responsável por reestruturar a relação sociedadenatureza em um molde menos predatório. No entanto, enfatiza-se a necessidade de englobar os adultos em atividades de EA, pois são eles os mais atuantes na realidade e nos diversos espaços.

Figura 14 - Grupos sociais alvo das práticas de EA.

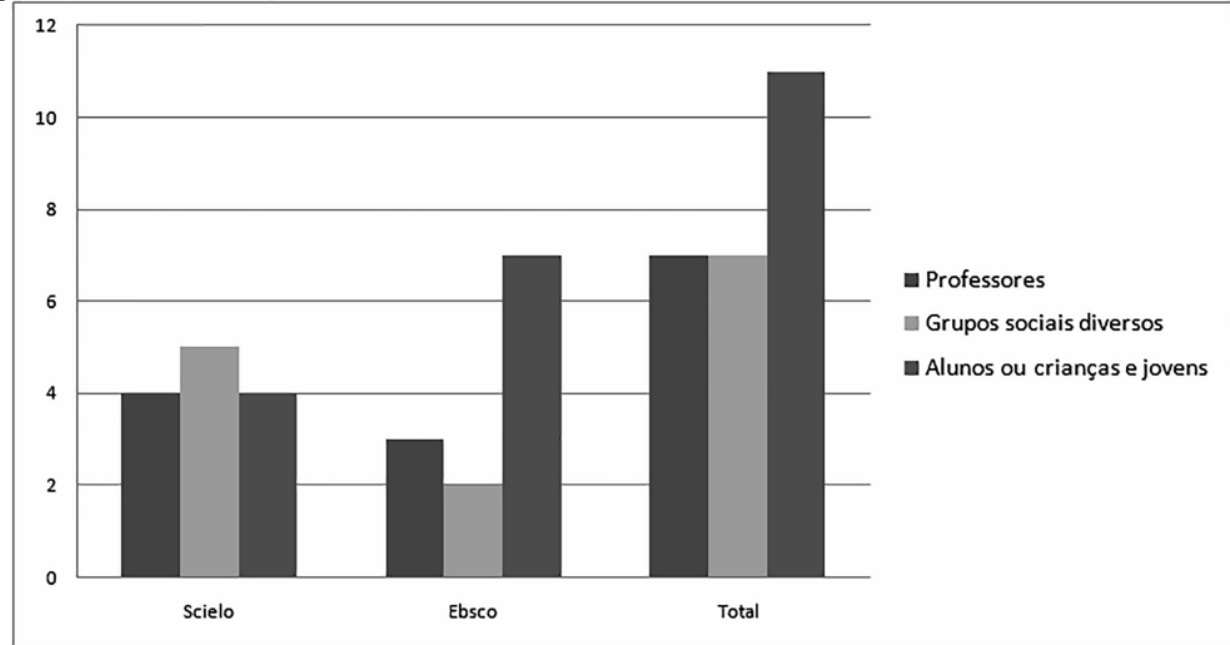

Fonte: da pesquisa. 
Vale destacar que as práticas de EA foram direcionadas tanto a um público específico, em 16 práticas (80\%) quanto a públicos diversos em quatro delas (20\%) (Figura 15). Aquelas que contemplaram grupos específicos tiveram as seguintes finalidades: formação de professores, em três (15\%); atividades de EA formais e não-formais (acampamento) com alunos ou crianças e jovens, em oito (40\%); e atividades de EA não-formais com grupos sociais variados, em cinco práticas (25\%) (Figura 16). As práticas de público misto, que somaram quatro (20\%), encontram-se dirigidas à: formação de professores articulada a atividades de EA de grupos sociais diversos em uma daspráticas (25\%); e atividades de EA com professores e alunos em duas delas (50\%). Bem como com a comunidade em uma (25\%) (Figura 17).

Figura 15 - Quantidade de públicos-alvo por práticas de EA voltadas às águas de BH.

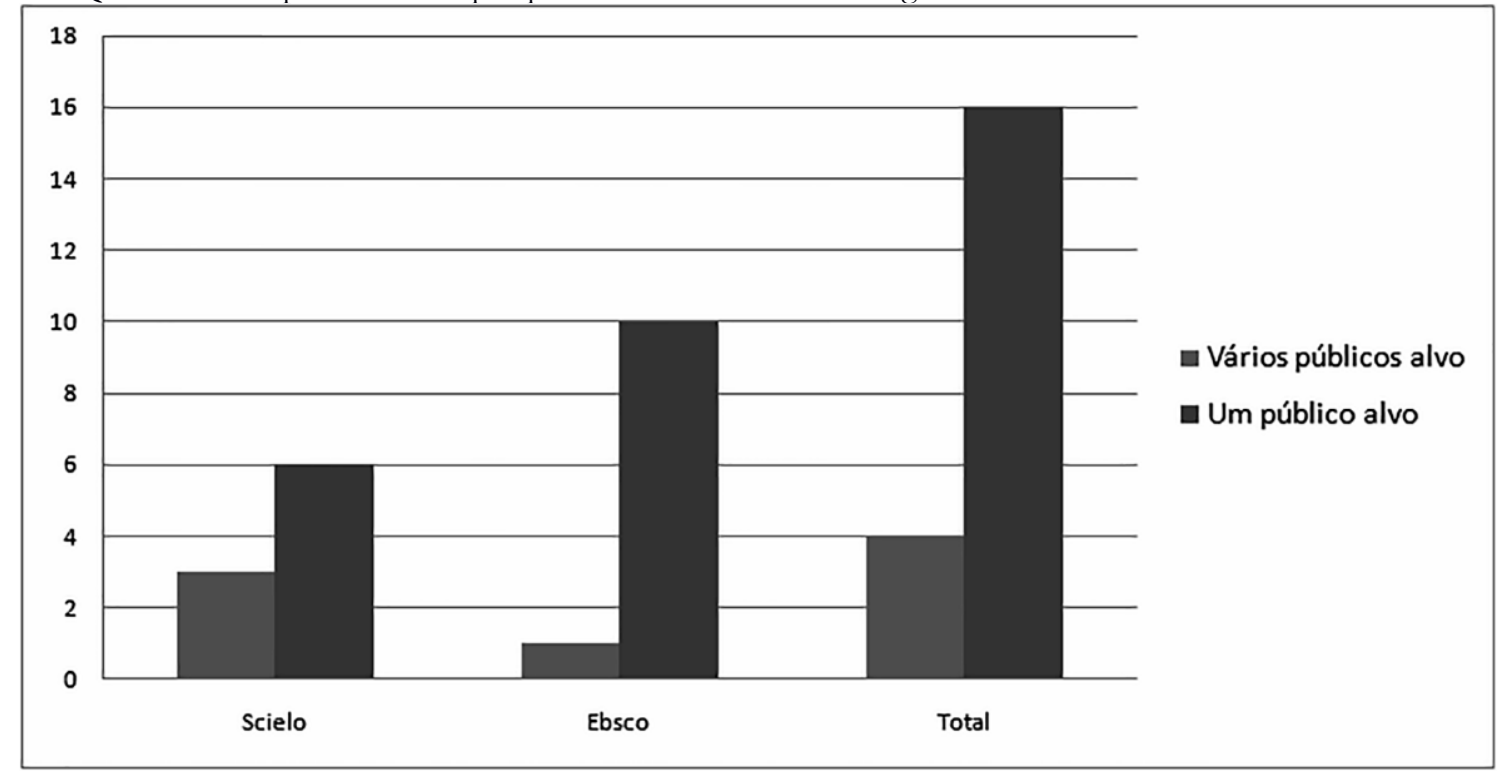

Fonte: da pesquisa.

Como se pôde ver até o momento, as práticas de EA englobam de maneira majoritária apenas um público, o que empobrece as possibilidades de seu desenvolvimento e a construção de um conhecimento coletivo calcado em olhares múltiplos. No entanto, elas atendem as necessidades específicas do público-alvo, o que permite obter resultados expressivos.

Figura 16 - Finalidades das práticas de EA.

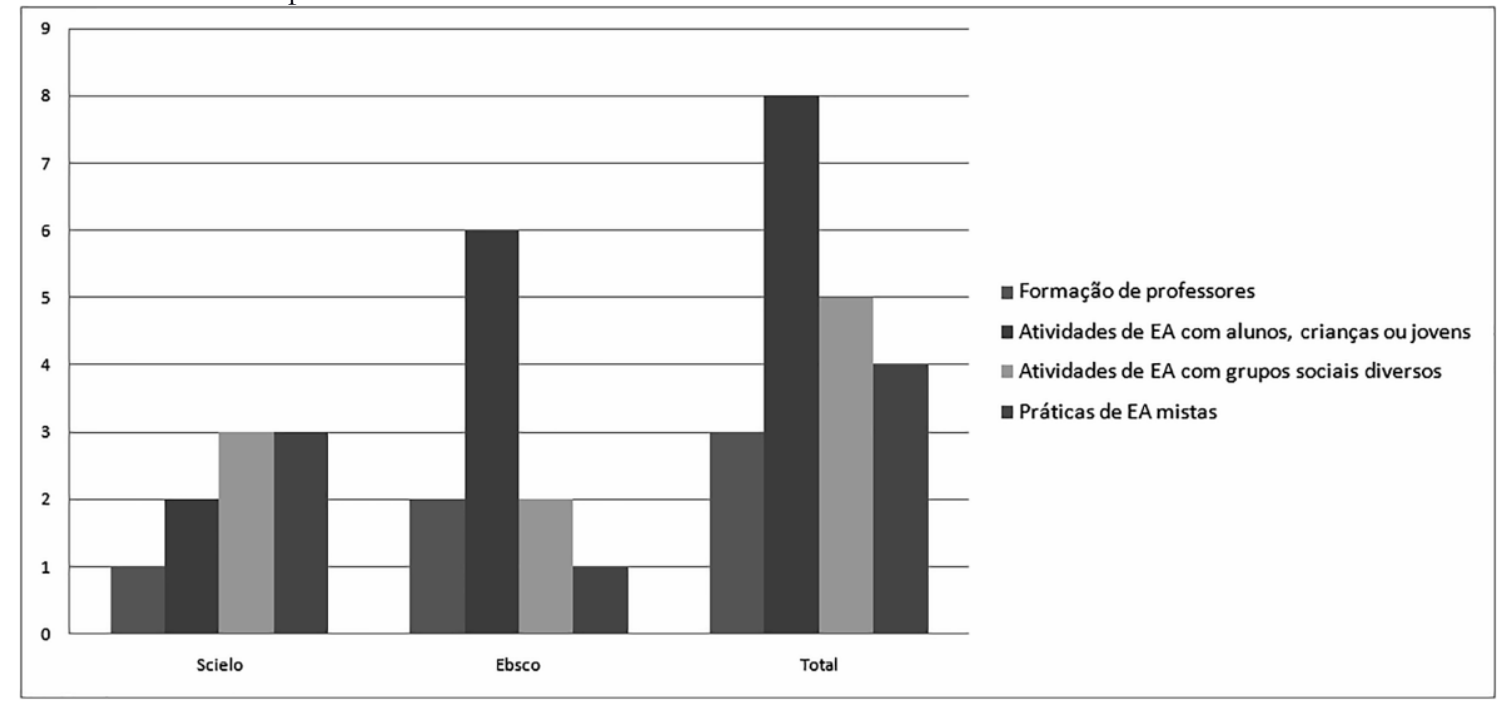

Fonte: da pesquisa. 
Também, verifica-se que as atividades direcionadas aos grupos jovens são tanto formais quanto não-formais, o que contribui para a diversificação das propostas de $\mathrm{EA}$, que são desenvolvidas sob prismas distintos. Destarte, ao se atingir o público jovem, podem-se obter resultados promissores na conservação das águas em BHs no presente e no futuro.

Figura 17 - Finalidade das práticas de EA mistas.

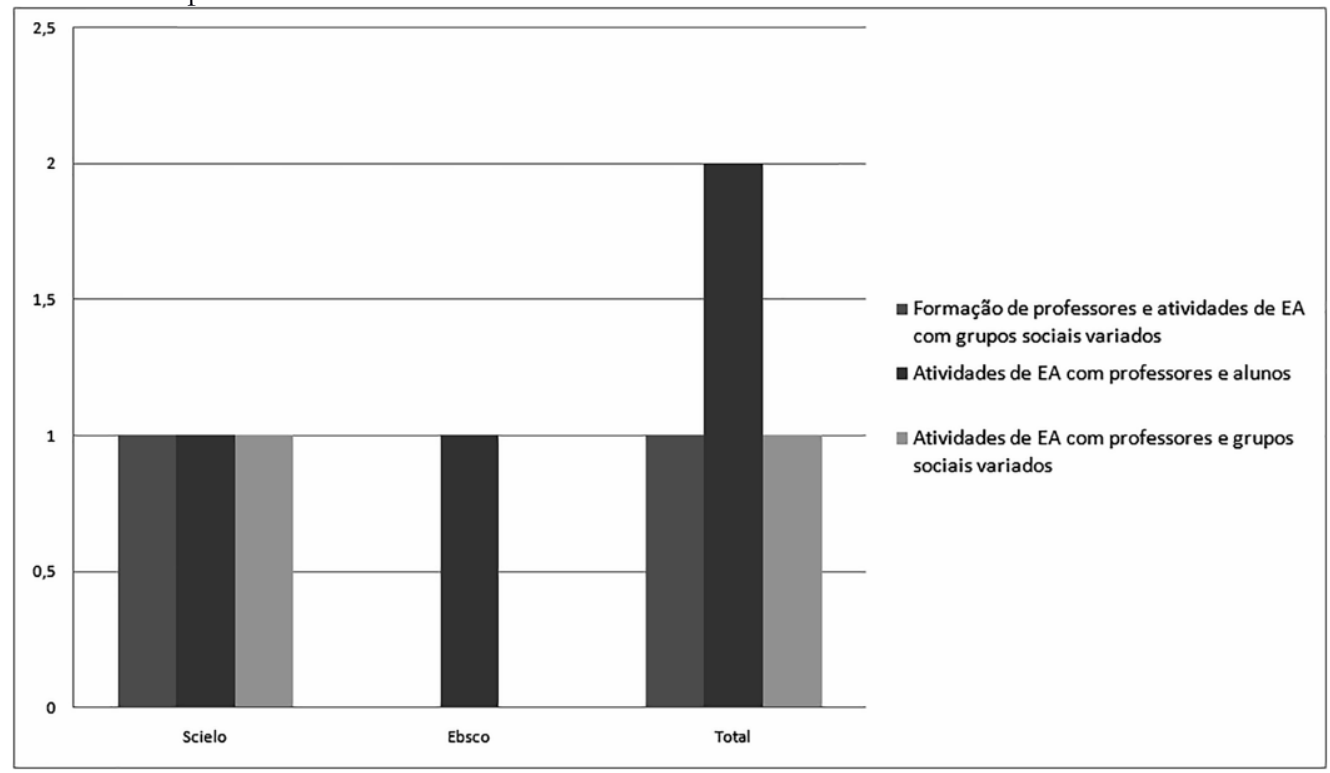

Fonte: da pesquisa.

Outro aspecto interessante é a existência de práticas direcionadas para a formação de professores que exploram a temática das águas em BHs. Nesse sentido, identifica-se a preocupação de que eles adquiram conhecimentos e estruturem atividades de EA que envolvam essa temática. Ademais, pensando sobre os objetivos almejados pelas práticas ${ }^{19}$, eles referem-se a aspectos teóricos e à realidade local em 17 práticas (85\%), de modo que os objetivos menos citados foram mudança comportamental em nove delas (45\%), mobilização em seis (30\%), gestão ambiental em cinco $(25 \%)$ e aspectos pedagógicos em cinco práticas(25\%) (Figura 18) ${ }^{20}$.

Figura 18 - Objetivos das práticas de EA voltadas às águas de $\mathrm{BH}$.

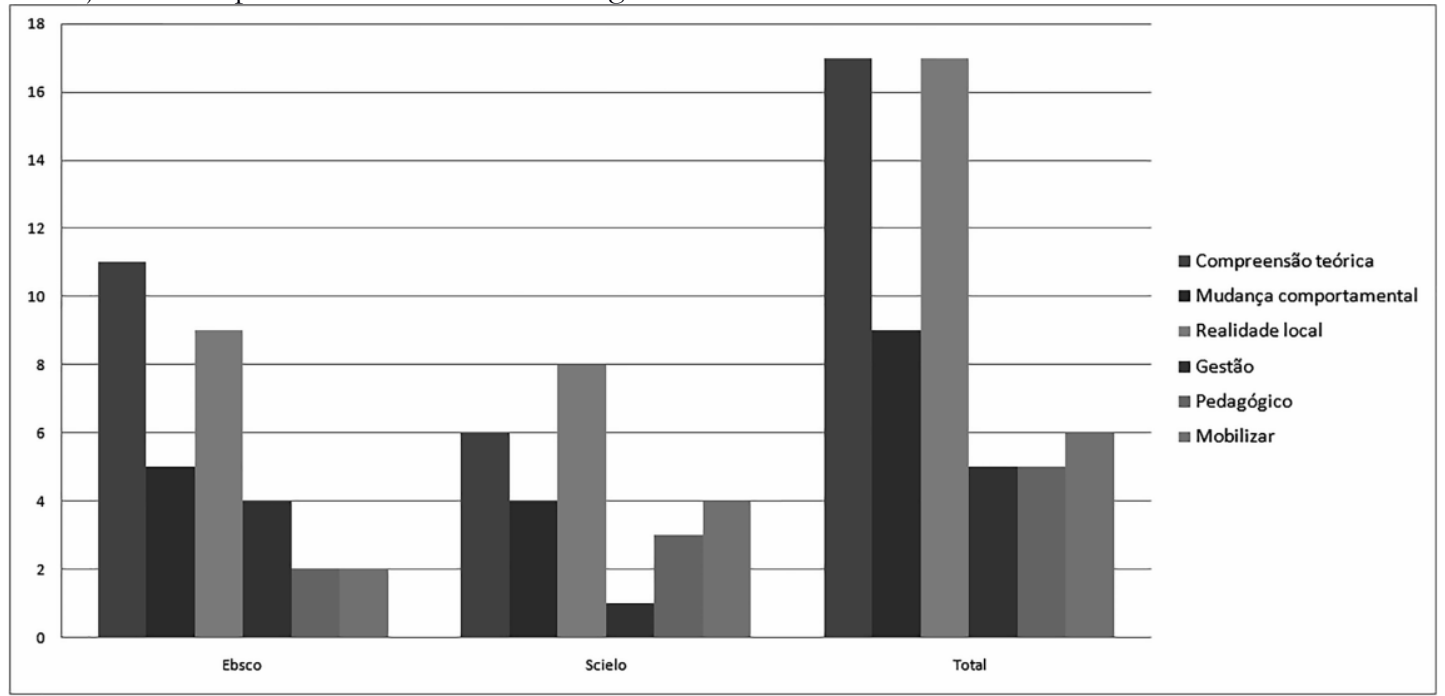

Fonte: da pesquisa.

19 Os objetivos são referentes às práticas de EA e não aos objetivos gerais dos artigos.

20 A porcentagem se refere à quantidade de artigos. A soma dos percentuais ultrapassa 100\%, pois as práticas de EA, em sua maioria, apresentavam mais de um objetivo. 
A título de explicar de outra maneira, o desmembramento dos dados da Figura 18 especifica os objetivos das práticas, como se demonstra no quadro 4.

Quadro 4 - Objetivos almejados pelas práticas de EA voltadas às águas de $\mathrm{BH}$

\begin{tabular}{|c|c|}
\hline Categoria & Objetivos \\
\hline Compreensão teórica & $\begin{array}{l}\text { - Conhecer informações e conceitos teóricos gerais sobre assuntos de } \\
\text { cunho ambiental; } \\
\text { - Aplicar os conhecimentos de cunho teórico em atividades práticas; } \\
\text { - Desenvolver a apreciação pela ciência; } \\
\text { - Envolver os participantes em pesquisas. }\end{array}$ \\
\hline Mudança comportamental & $\begin{array}{l}\text { - Desenvolver habilidades, valores e atitudes para a proteção ambiental; } \\
\text { - Promover a liderança; } \\
\text { - Conscientizar, sensibilizar ou motivar para a proteção e a revitalização } \\
\text { ambiental; } \\
\text { - Conscientizar para o uso de ações práticas que visem à preservação } \\
\text { ambiental }\end{array}$ \\
\hline Realidade local & $\begin{array}{l}\text { - Compreender as características da realidade que os participantes estão } \\
\text { envolvidos em seu cotidiano ou de estudo; } \\
\text { - Proporcionar a integração dos participantes ou entidade promotora } \\
\text { das práticas de EA com a comunidade local; } \\
\text { - Propor soluções aos problemas ambientais locais; } \\
\text { - Desenvolver a afetividade ou apreciação pelo lugar, natureza ou } \\
\text { atividades ao ar livre; } \\
\text { - Desconstruir o desinteresse e o desapego às questões ambientais } \\
\text { locais. }\end{array}$ \\
\hline Gestão & $\begin{array}{l}\text { - Promover a gestão ou conservação ambiental; } \\
\text { - Criar planejamentos para o uso dos espaços, } \\
\text { - Compreender as consequências das decisões sobre os ambientes. }\end{array}$ \\
\hline Pedagógico & $\begin{array}{l}\text { - Aumentar o uso de recursos pedagógicos variados na área de EA; } \\
\text { - Aumentar o nível de confiança dos participantes em ensinar conteúdos } \\
\text { ambientais; } \\
\text { - Examinar e construir atividades, projetos ou currículos de ensino de } \\
\text { cunho ambiental e sua implementação em sala de aula. }\end{array}$ \\
\hline Mobilização & $\begin{array}{l}\text { - Compartilhar experiências, informações ou conhecimentos com } \\
\text { outras pessoas ou com a sociedade sobre a questão ambiental; } \\
\text { - Implementar ações práticas que visem à proteção ambiental; } \\
\text { - Produzir material educativo para divulgação; } \\
\text { - Formar grupo de multiplicadores; } \\
\text { - Mobilizar para a preservação ambiental ou conservação de recursos } \\
\text { naturais. }\end{array}$ \\
\hline
\end{tabular}

Fonte: da pesquisa.

Ainda, a exploração dos aspectos teóricos e a abordagem da realidade local obtiveram destaque entre os objetivos almejados, pois percebe-se que se deixa as demais habilidades e possibilidades de EA em segundo plano, mesmo considerando-se que tratar da realidade local é relevante, pois a EA voltada à compreensão e ao estudo local objetiva uma aprendizagem significativa e uma identificação dos envolvidos com o espaço vivido (MEICHTRY; SMITH, 2007). Quanto ao método ${ }^{21}$, as atividades de

21 Foi levado em consideração apenas o método que embasou a aplicação e o desenvolvimento das atividades de EA e não os métodos empregados na avaliação e análise dos resultados da pesquisa.

Educação em Revista|Belo Horizonte|v.36|e217885|2020 
EA voltadas às águas de $\mathrm{BH}$ ou empregaram a pesquisa-ação em quatro práticas(20\%); ou não especificaram o seu método em 16 delas (80\%) (Figura 19).

Figura 19 - Método empregado no desenvolvimento da atividade de EA voltada às águas de $\mathrm{BH}$.

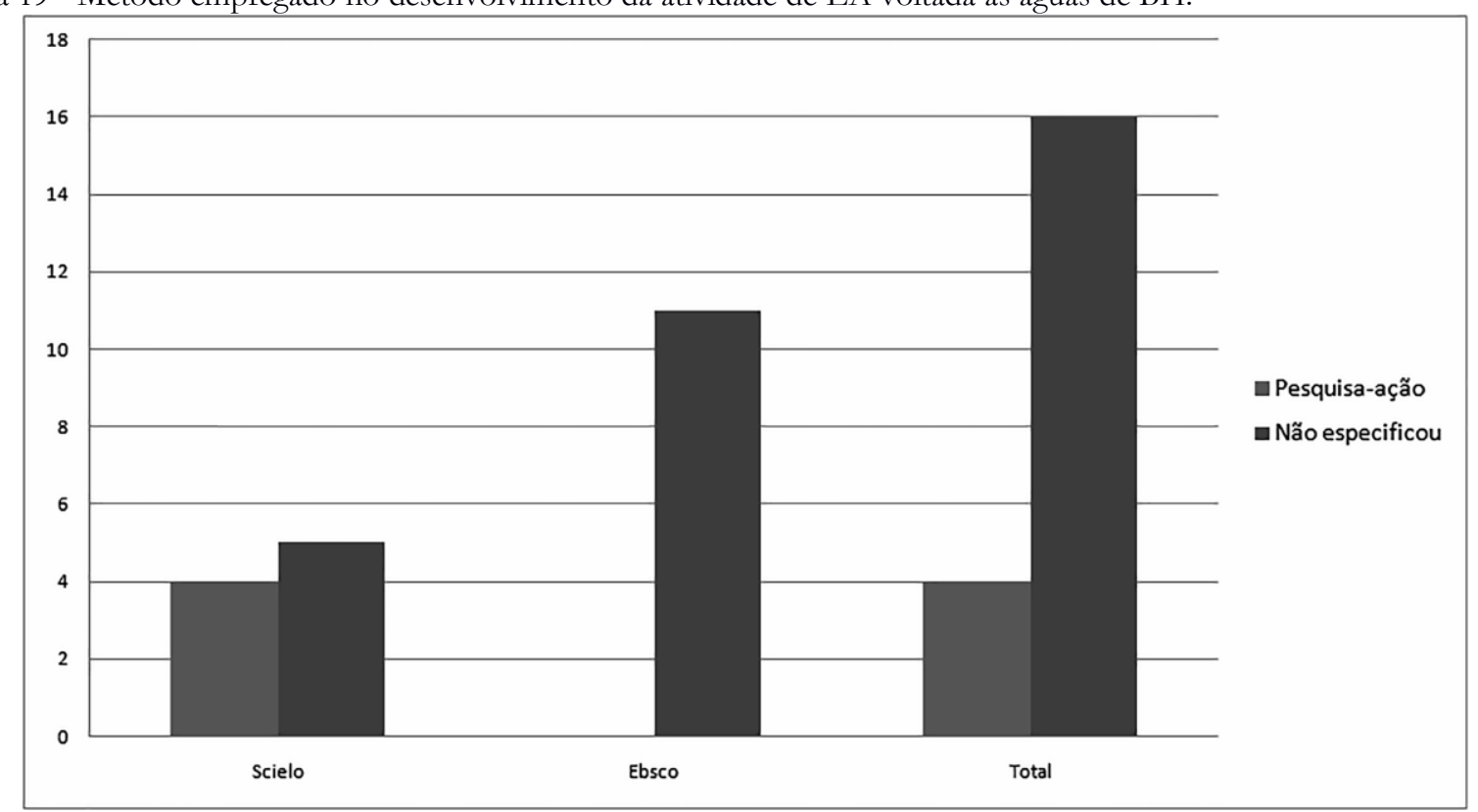

Fonte: da pesquisa.

A pesquisa-ação é uma pesquisa social estruturada e associada a uma ação ou a solução de uma problemática real, em que pesquisadores e envolvidos estão articulados cooperativa e participativamente (THIOLLENT, 2011). As quatro práticas de EA que utilizaram esse método possuem direcionamentos distintos, sendo que as propostas de Santos, Medeiros e Silva (2013) e de Obara et al. (2015) descrevem atividades de EA desenvolvidas com uma comunidade local; já Lucatto e Talamoni (2007) tratam de uma ação de formação de professores que desenvolve conjuntamente um plano de atividades pedagógicas que são aplicadas com alunos; e a proposta de Piccoli et al. (2016) trata de uma construção metodológica de mobilização da sociedade para resolução de problemática local.

Essas práticas de EA envolveram o seu público-alvo em todas as etapas de desenvolvimento, de modo a integrar o planejamento das atividades a serem desenvolvidas; a identificação de problemas relativos à temática de análise; o levantamento de informações e a construção de conhecimentos sobre a realidade local; a análise, a reflexão e a tomada de decisões durante o desenvolvimento das atividades; bem como a definição de propostas de ação. Nesse sentido, observa-se que existe um processo de construção coletivo, que leva em conta os conhecimentos locais e que permite uma atuação ativa e reflexiva de todos os envolvidos nesse processo.

As práticas que não especificaram o método passaram por uma análise que permitiu identificar as suas principais etapas metodológicas ${ }^{22}$, ao que se verificou que todas elas desenvolveram a etapa da capacitação; porém somente $11(69 \%)$ favoreceram o conhecimento e a discussão da realidade estudada e nove $(56 \%)$ produziram conhecimento sobre o local de estudo. A proposição de soluções aos problemas locais, a criação de propostas pedagógicas e sua implementação aparecem como etapas em duas práticas apenas (13\%), enquanto discutir e negociar os problemas e soluções com as autoridades locais e implementar ações aparece em uma (6\%) (Figura 20). Diante disso, pode-se verificar que as práticas de $\mathrm{EA}$ voltadas às águas de $\mathrm{BH}$ focam no conhecimento teórico e na realidade local. No entanto, pouco se faz com relação ao planejamento, proposição e aplicação de ações que possam, efetivamente, promover mudanças nas realidades estudadas.

22 Essas etapas metodológicas são simplificações teóricas e apresentam apenas as características comuns entre as pesquisas, não apresentando a gama de características específicas de cada prática de EA.

Educação em Revista|Belo Horizonte|v.36|e217885|2020 
Figura 20 - Etapas metodológicas das práticas de EA voltada às águas de $\mathrm{BH}$.

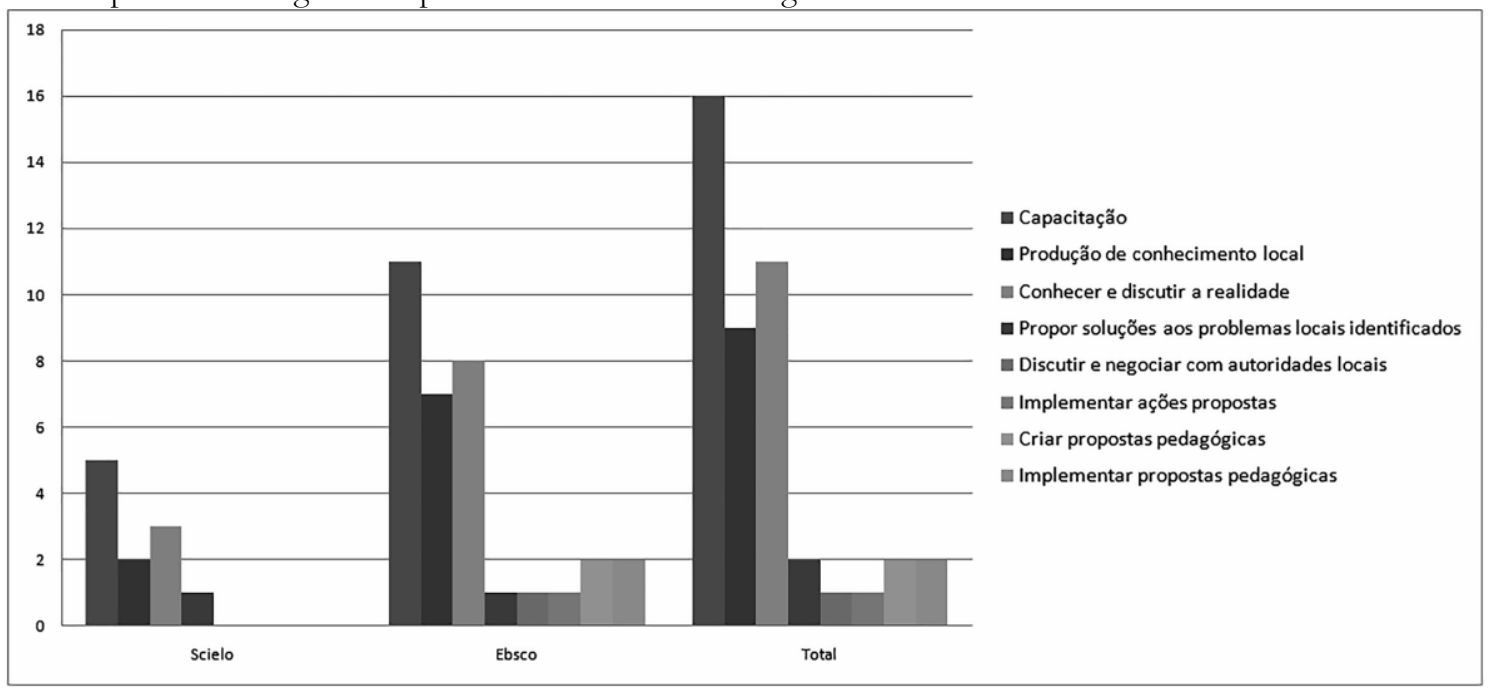

Fonte: da pesquisa.

Quadro 5 - Estratégias pedagógicas empregadas nas atividades de EA voltadas às águas de BH.

\begin{tabular}{|c|c|}
\hline Categorias & Atividades desenvolvidas \\
\hline Atividades práticas & $\begin{array}{l}\text { Observação; participação em jogo, atividade de recreação, desportiva, } \\
\text { brincadeira e atividade livre; coleta de sementes; plantação de árvores; } \\
\text { coleta de amostra de água e animais aquáticos; experimento em campo } \\
\text { ou laboratório; construção de composteira e horta; confecção de papel; } \\
\text { utilização de equipamento de medição, GPS e ferramentas } \\
\text { tecnológicas; implementação de práticas agrícolas sustentáveis ou } \\
\text { confecção de camiseta. }\end{array}$ \\
\hline Exercício escrito & $\begin{array}{l}\text { Resolução de cálculo; preenchimento de protocolo, questionário e } \\
\text { caderno de campo; realização de pesquisa em documentos e livros; } \\
\text { confecção de desenho, história em quadrinhos, gráfico, tabela, } \\
\text { diagrama, mapa, apresentação e flanelógrafo ou análise SWOT. }\end{array}$ \\
\hline Atividades em grupo & Reunião e conversa em grupo (presencial ou on-line). \\
\hline $\begin{array}{c}\text { Eventos ou aulas } \\
\text { expositivas }\end{array}$ & $\begin{array}{l}\text { Participação em curso, palestra, workshop, oficina ou exposição } \\
\text { itinerante. }\end{array}$ \\
\hline Atividades de campo & $\begin{array}{l}\text { Visita a área natural, viveiro de árvores, museu, rio, nascente e jardim } \\
\text { botânico. }\end{array}$ \\
\hline Leituras & Leitura de folheto, texto, documento, cartaz, notícia de jornal e site. \\
\hline Imagens, filmes e músicas & $\begin{array}{l}\text { A análise de imagens como fotografia, mapa, fotos aéreas e gráfico. } \\
\text { Análise de filmes e músicas. }\end{array}$ \\
\hline $\begin{array}{l}\text { Material educativo e } \\
\text { informativo para } \\
\text { divulgação }\end{array}$ & $\begin{array}{l}\text { Construção de livro didático, folheto, apresentação, atividade de EA, } \\
\text { banner, seminário, reunião, site e notícia nos meios de comunicação. }\end{array}$ \\
\hline Atividades pedagógicas & $\begin{array}{l}\text { Elaboração de propostas de atividades pedagógicas que visavam } \\
\text { estruturar atividades de EA para serem aplicadas com alunos em sala } \\
\text { de aula. }\end{array}$ \\
\hline
\end{tabular}

Fonte: da pesquisa.

Diversas estratégias pedagógicas foram empregadas nas práticas de EA. Elas foram divididas em grupos com atividades semelhantes, como pode-se observar no quadro 5. 
Essas atividades desenvolvidas com os participantes da EA, foram de cunho prático em sua maioria, somando 48 atividades, o que equivale a $22 \%$ do total nas experiências de $\mathrm{EA}^{23}$. Na sequência, têm-se os exercícios escritos totalizando 38 ocorrências (17\%); a participação de atividades em grupo com 36 (16\%); participação em eventos ou aulas expositivas com 25 (11\%) e atividade de campo com 23 $(10 \%)$.

Já as atividades que tiveram menor expressão na EA foram: leitura de textos com 14 ocorrências (6\%); análise de imagens, filmes e músicas com 13 (6\%); construção de material educativo e de divulgação com 9 (4\%); atividades interativas com $6(3 \%)$; criação de atividades pedagógicas com 6 $(3 \%)$ e atividades de sistematização de ideias com $3(1 \%)$ (Figura 21$)^{24}$.

Figura 21 - Estratégias pedagógicas utilizadas na EA voltada às águas de $\mathrm{BH}$.

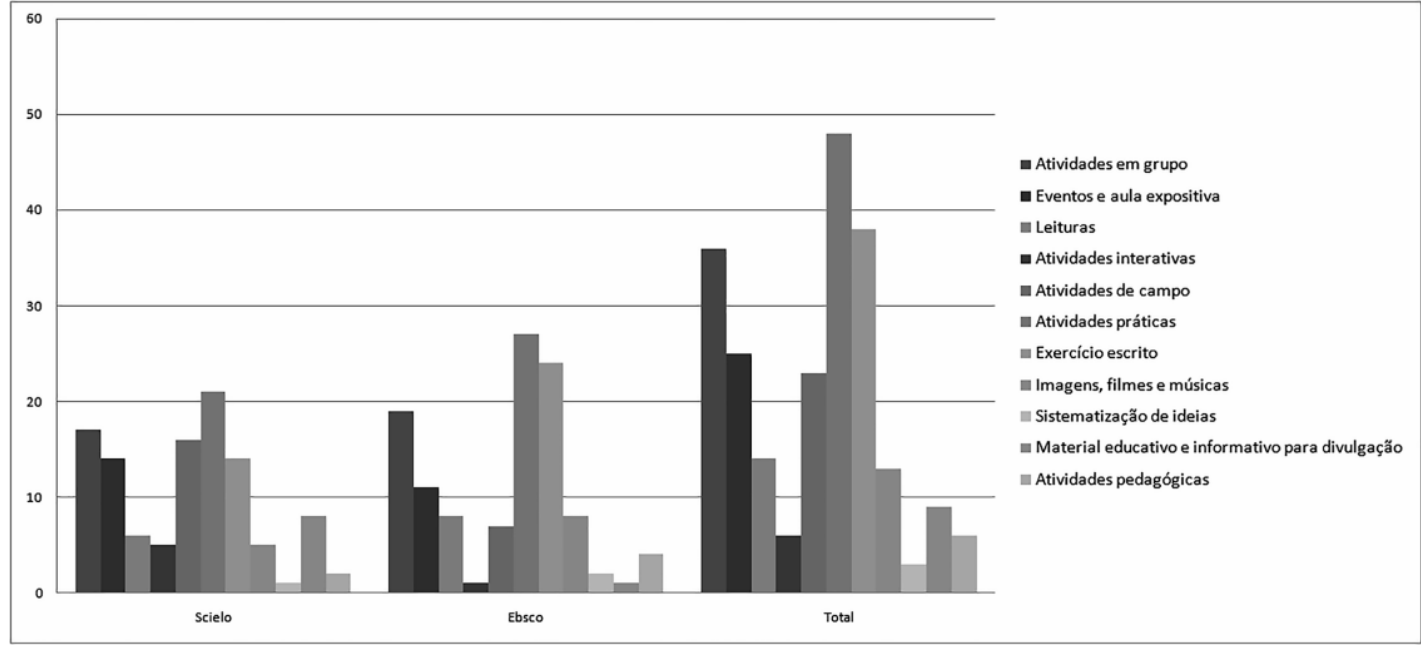

Fonte: da pesquisa.

Observa-se, também, que as estratégias pedagógicas das práticas de EA incluem atividades de interação prática e dinâmica com 116 atividades (52\%). No entanto, não se tem uma diferença significativa em relação às atividades de interação tradicional com 96 (43\%) (Figura 22). Todavia, diferentes estratégias atendem às diversificadas necessidades do público, sendo bastante relevante dar-se conta das demandas deles (a Figura 22 sintetiza essas escolhas mais ou menos dinâmicas).

Figura 22 - Estratégias pedagógicas utilizadas no desenvolvimento das práticas de EA voltada às águas de $\mathrm{BH}$.

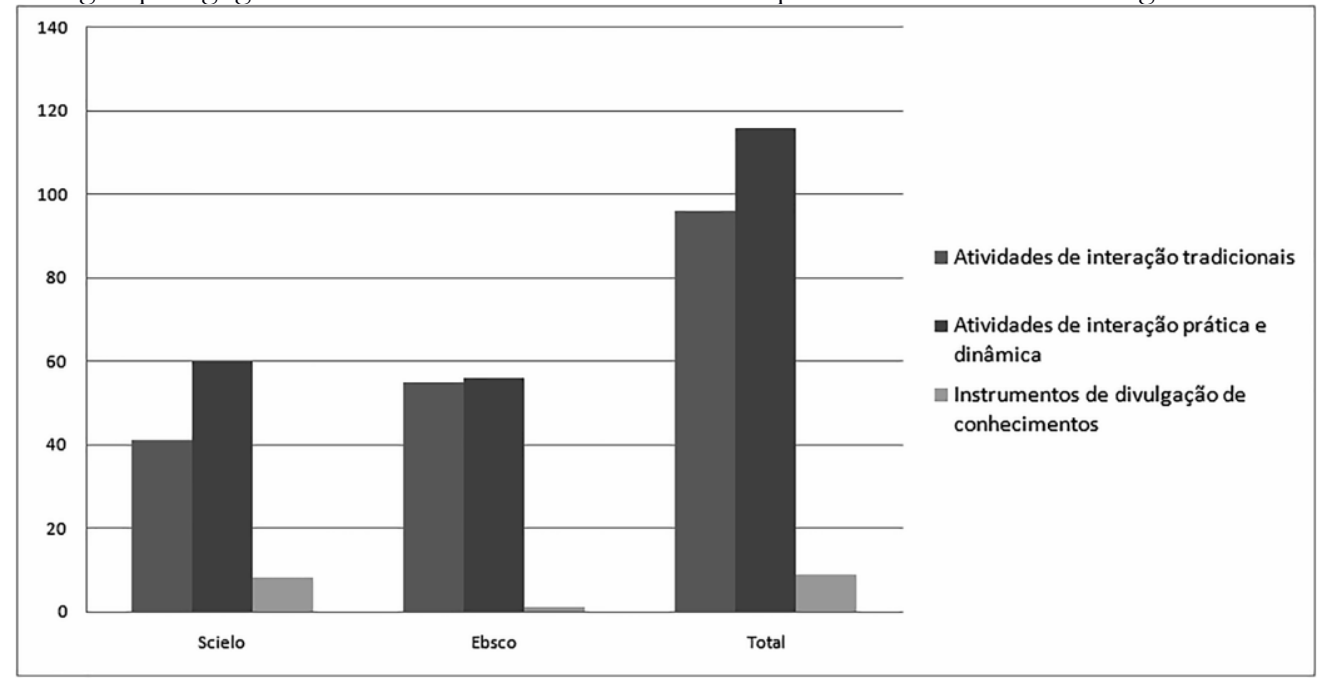

Fonte: da pesquisa.

23 Cada prática de EA envolveu diversas atividades, por vezes empregando várias atividades do mesmo tipo, sendo todas contabilizadas.

24 O $1 \%$ que falta refere-se aos números fracionados decorrentes do cálculo de porcentagem.

Educação em Revista|Belo Horizonte|v.36|e217885|2020 
Verificou-se, ainda, que 16 (80\%) práticas de EA articularam atividades práticas e teóricas (Figura 23). Aspecto que é interessante, pois permite uma diversidade de oportunidades para uma aprendizagem significativa dos participantes.

Figura 23 - Articulação de atividades teóricas e práticas.

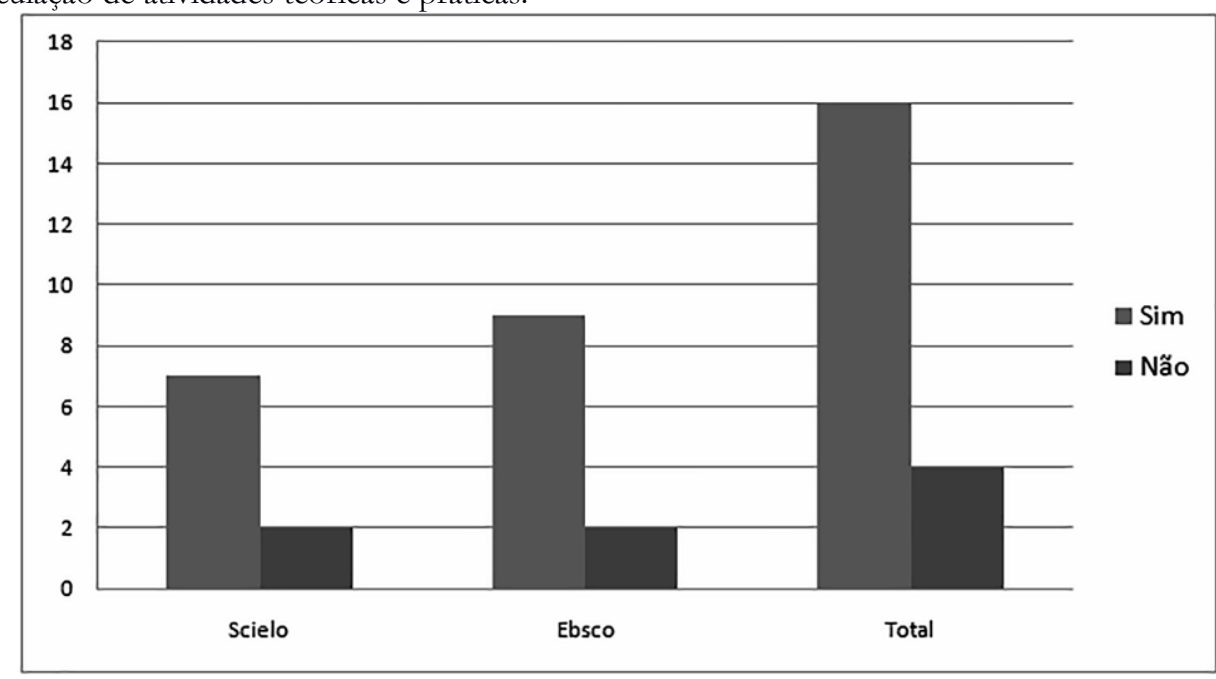

Fonte: da pesquisa.

Em suma, pode-se destacar que as estratégias pedagógicas que envolveram as práticas de EA são variadas, no entanto, as atividades de EA mantêm estratégias pedagógicas tradicionais com relevância, englobando uma gama de atividades interativas e articulando ações teóricas e práticas em seu desenvolvimento. Essas escolhas permitem a estruturação de um espaço amplo para descobertas frente ao meio ambiente, o que pode ser marcante aos participantes, pois quanto maiores as possibilidades de experiência dos participantes com a questão ambiental, mais significativas e intensas poderão ser as aprendizagens.

Os resultados ${ }^{25}$ positivos e negativos, assim como as sugestões apresentadas pelos artigos foram avaliados. Os resultados positivos identificados foram categorizados conforme o quadro 6.

Quadro 6 - Categorização dos resultados positivos das práticas de EA voltadas às águas de BH.

\begin{tabular}{|c|l|}
\hline Categorias & \multicolumn{1}{c|}{ Resultados positivos alcançados } \\
\hline $\begin{array}{c}\text { Compreensão } \\
\text { teórica }\end{array}$ & - Entendimento de informações e conteúdos teóricos; \\
\hline & - Adaptação das explicações e informações teóricas ao grupo alvo. \\
\hline & - Criação de habilidades, atitudes e valores para a conservação ambiental; \\
& - Constituição de cidadãos e sujeitos ativos, confiantes, conscientes, críticos, \\
empoderados e autônomos (individual ou coletiva) no processo de tomada de \\
decisões sobre a realidade vivenciada.
\end{tabular}

25 Os resultados avaliados são aqueles relacionados ao desenvolvimento das práticas de EA voltadas às águas de $\mathrm{BH}$. Nesse sentido, não são avaliados todos os resultados apresentados pelos artigos, que nem sempre apresentam somente esses resultados. 


\begin{tabular}{|c|c|}
\hline Realidade local & $\begin{array}{l}\text { - Compreender a realidade local ou bacia hidrográfica: características e } \\
\text { problemas do ambiente local; } \\
\text { - Estabelecer soluções aos problemas locais de forma coletiva; } \\
\text { - Efetivar ou influenciar as ações para a solução dos problemas e desafios locais } \\
\text { de maneira coletiva; } \\
\text { - Conhecimento prévio sobre a realidade local; } \\
\text { - Criar afetividade, apego e admiração pelo lugar, natureza e atividades ao ar } \\
\text { livre; } \\
\text { - Melhoria na qualidade de vida, benefícios econômicos e ambientais com a } \\
\text { implementação de ações sustentáveis no ambiente local; } \\
\text { - As comunidades locais se tornaram mais sustentáveis ambientalmente, } \\
\text { socialmente e economicamente; } \\
\text { - Os temas e assuntos tratados foram considerados relevantes para a tomada } \\
\text { de decisões sobre a realidade local. }\end{array}$ \\
\hline Pedas & $\begin{array}{l}\text { - As atividades didático-pedagógicas foram consideradas criativas, promoveram } \\
\text { uma educação dinâmica e interativa, geraram entusiasmo e participação ativa e } \\
\text { articularam conhecimentos teóricos e ações; } \\
\text { - Mudanças nas práticas pedagógicas dos participantes: alteração na concepção } \\
\text { de como trabalhar a EA; } \\
\text { - O ambiente local ou a bacia hidrográfica se tornou a base adequada para o } \\
\text { desenvolvimento das práticas de ensino voltadas às questões ambientais; } \\
\text { - Maioria dos participantes já tratava de assuntos ambientais (recursos hídricos } \\
\text { e BH) em sala de aula; } \\
\text { - Utilização de metodologias, materiais e atividades diversificadas no } \\
\text { desenvolvimento das práticas de EA; } \\
\text { - Conscientização quanto à importância de discutir os assuntos ambientais } \\
\text { relativos à realidade local com os alunos em sala de aula; } \\
\text { - Desenvolvimento da confiança e da capacidade de ensinar e utilizar } \\
\text { determinados recursos pedagógicos em atividades de EA; } \\
\text { - As atividades de EA foram adaptadas à realidade socioeconômica dos } \\
\text { participantes; } \\
\text { - As atividades ao ar livre ou trabalho de campo são relevantes e contribuem } \\
\text { para o aprendizado dos participantes. }\end{array}$ \\
\hline Mobil & $\begin{array}{l}\text { - Disseminação de informações, conhecimentos e discussões para a sociedade } \\
\text { com o uso de folhetos impressos, banco de dados, multiplicadores, eventos, } \\
\text { envolvimento dos cidadãos e dos órgãos responsáveis nas discussões } \\
\text { desenvolvidas referente à questão ambiental; } \\
\text { - Os conhecimentos apreendidos serão utilizados nas ações futuras dos } \\
\text { participantes. }\end{array}$ \\
\hline Participação & $\begin{array}{l}\text { - Interesse em permanecer participando das práticas de EA; } \\
\text { - Motivação e participação ativa nas discussões e execução das atividades de } \\
\text { EA. }\end{array}$ \\
\hline Coletividade & $\begin{array}{l}\text { - Aprendizagem coletiva: aprender, discutir, trocar ideias e informações } \\
\text { coletivamente; } \\
\text { - Articulação e interação entre os saberes científicos e populares; } \\
\text { - Interação dos diferentes atores sociais (alunos, entidades e população) nas } \\
\text { atividades de EA; } \\
\text { - Capacidade de negociar, discutir, tomar decisões e ouvir o conjunto de atores } \\
\text { sociais envolvidos. }\end{array}$ \\
\hline
\end{tabular}

Fonte: da pesquisa. 
Os resultados positivos alcançados nas práticas de EA estiveram voltados, em sua maioria, para a compreensão teórica, a mudança comportamental e a compreensão da realidade local, cada uma com 13 práticas $(65 \%)$ de EA que apresentaram esses resultados. A articulação coletiva veio em seguida com 12 práticas $(60 \%)$ e os aspectos pedagógicos e a participação com 10 práticas $(50 \%)$ cada uma (Figura 24). Os resultados que foram menos expressivos foram os relacionados à mobilização, apresentando somente sete práticas (35\%), enquanto apenas uma $(5 \%)$ não apresentou nenhum tipo de resultado, pois ela não foi realizada.

Figura 24 - Resultados positivos atingidos nas práticas de EA voltadas às águas de $\mathrm{BH}$.

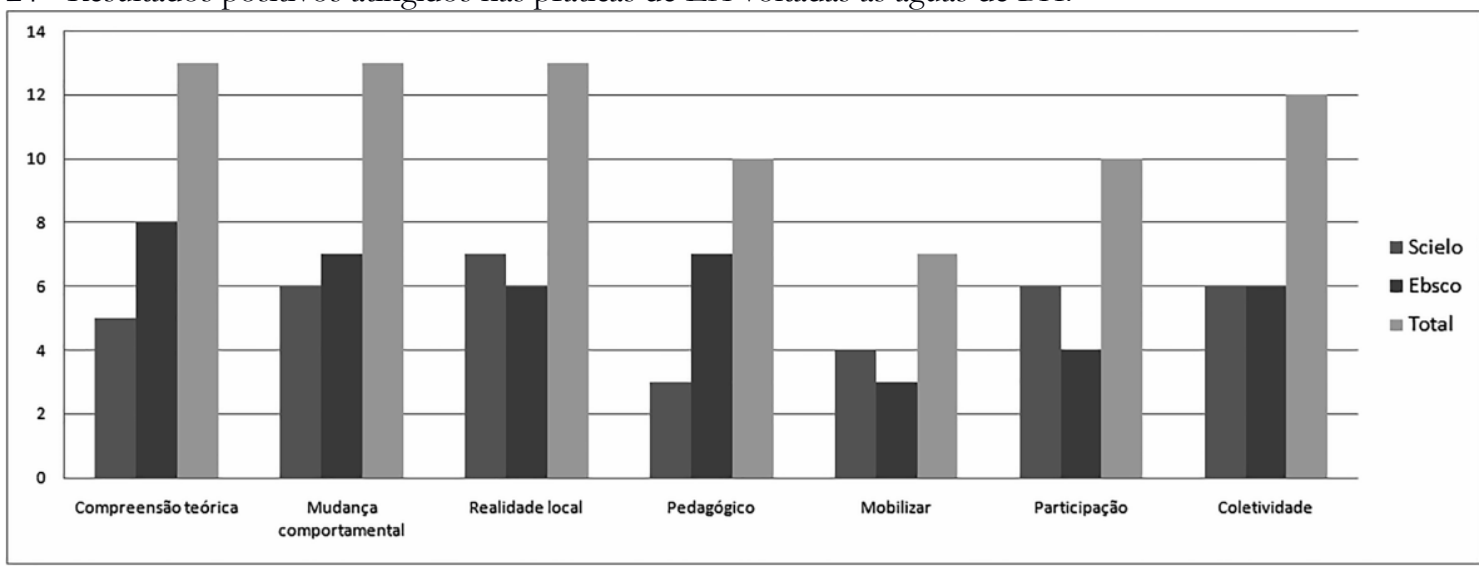

Fonte: da pesquisa.

Nesse sentido, percebe-se que quase todas as categorias de resultados positivos estiveram presentes na metade ou em mais da metade das práticas avaliadas. Porém, elas visaram de forma restrita a mobilização dos participantes e da sociedade. Esse aspecto necessita ser trabalhado e desenvolvido pelas práticas de EA voltada às águas de $\mathrm{BH}$ como um dos caminhos para o seu aprimoramento. Isso porque, a mobilização é tida como relevante para que a EA possa ultrapassar o público-alvo, transpondo o espaço em que ela se desenvolveu e se irradiando pela sociedade. Assim, permite o alcance de resultados mesmo após o seu encerramento, sendo possível a sua continuidade no tempo e no espaço. A mobilização é essencial para a participação nos processos de gestão das águas no contexto das bacias hidrográficas.

Além dos resultados positivos os artigos identificaram resultados negativos, que foram categorizados conforme quadro 7.

Quadro 7 - Categorização dos resultados negativos das práticas de EA voltadas às águas de $\mathrm{BH}$.

\begin{tabular}{|c|c|}
\hline Categorias & Resultados negativos identificados \\
\hline Compreensão teórica & $\begin{array}{l}\text { - Não foi identificada se a compreensão teórica alterou as atitudes frente ao ambiente } \\
\text { local; } \\
\text { - Poucos conhecimentos teóricos prévios; } \\
\text { - Dificuldades de executar as tarefas devido à falta de conhecimentos teóricos; } \\
\text { - Dificuldade de articular conhecimento teóricos com contextos práticos; } \\
\text { - Falta de compreensão sobre os conceitos teóricos; } \\
\text { - Não foi identificada qual a compreensão sobre os assuntos tratados; } \\
\text { - Dificuldade de monitorar os conhecimentos adquiridos; } \\
\text { - Recebimento de poucas informações sobre os assuntos tratados. }\end{array}$ \\
\hline $\begin{array}{c}\text { Mudança } \\
\text { Comportamental }\end{array}$ & $\begin{array}{l}\text { - O impacto emancipatório da prática de EA foi pequeno; } \\
\text { - Não foram identificadas alterações no entusiasmo pela ciência e pelo estudo do } \\
\text { espaço local; } \\
\text { - Dificuldade dos participantes em refletirem sobre o seu uso da água. }\end{array}$ \\
\hline Realidade local & $\begin{array}{l}\text { - Pouco ou nenhum conhecimento sobre a realidade ou bacia hidrográfica local; } \\
\text { - Poucas informações disponíveis sobre a realidade ou bacia hidrográfica local } \\
\text { adaptada aos diferentes públicos; } \\
\text { - Inicialmente existia uma imagem negativa do rio local; }\end{array}$ \\
\hline
\end{tabular}

Educação em Revista|Belo Horizonte|v.36|e217885|2020 


\begin{tabular}{|c|l|}
\hline & - Pouco interesse na discussão das problemáticas ambientais locais; \\
& - As características socioeconômicas da realidade local afetou as práticas de EA. \\
\hline \multirow{5}{*}{ Pedagógico } & - A prática de EA apresentou limitações (por ser pontual ou fragmentada); \\
& - Resistência em desenvolver práticas de EA de maneira interdisciplinar; \\
& - Dificuldades em trabalhar assuntos ambientais em sala de aula devido a estrutura \\
inadequada da escola, restrições curriculares, compreensão tradicional de EA, EA \\
desenvolvida poucas vezes e desvinculada da realidade local, etc.; \\
& $\begin{array}{l}\text { - As atividades desenvolvidas não foram condizentes com a realidade dos } \\
\text { participantes, foram desenvolvidas em momentos pouco oportunos, foram pouco } \\
\text { exploradas, tiveram limitado valor educativo, não foram bem aceitas, etc. }\end{array}$ \\
\hline \multirow{3}{*}{ Mobilização } & $\begin{array}{l}\text { - Poder de decisão restrito nas práticas de EA, o que limitou a discussão e o } \\
\text { envolvimento democrático nas decisões tomadas. }\end{array}$ \\
\hline \multirow{3}{*}{ Participação } & $\begin{array}{l}\text { - Dificuldades de envolver professores de todas as áreas do conhecimento; } \\
\text { - Baixa participação; } \\
\text { - Dificuldades em participar e desenvolver as atividades de EA devido a transporte } \\
\text { ineficiente, tempo e financiamentos insuficientes para avaliar e acompanhar as } \\
\text { práticas de EA. }\end{array}$ \\
\hline
\end{tabular}

Fonte: da pesquisa.

Dentre as práticas, em $12(60 \%)$ identificaram-se resultados negativos. Em sua maioria, estavam relacionados à compreensão teórica e aos aspectos pedagógicos com sete $(58 \%)^{26}$ práticas cada um. A compreensão da realidade local também obteve destaque com seis $(50 \%)$ práticas. Os resultados negativos que apresentaram menor destaque foram: a participação com quatro (33\%); a mudança comportamental com três (25\%); e a mobilização com uma (8\%) prática (Figura 25).

Figura 25 - Resultados negativos identificados pelas práticas de EA voltadas às águas de $\mathrm{BH}$.

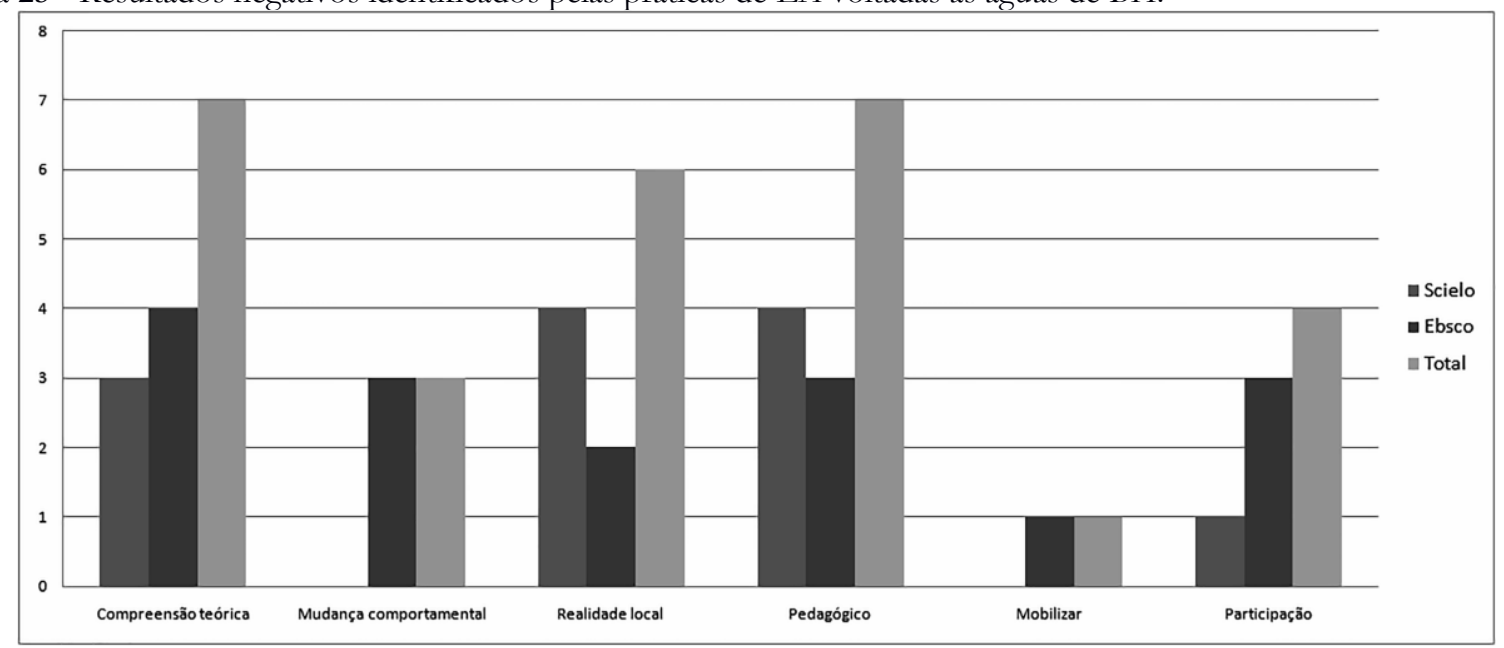

Fonte: da pesquisa.

Observou-se que um número significativo de práticas apresentou resultados negativos, o que evidencia que os pesquisadores estiveram atentos e tiveram uma postura crítica frente aos estudos de EA que empreenderam, levando para a discussão os aspectos que foram falhos e que por sua vez necessitaram de reflexão.

Nos artigos também foram apresentadas sugestões para o aprimoramento das práticas de EA, categorizadas conforme quadro 8.

Quadro 8 - Categorização das sugestões apresentadas nas práticas de EA voltadas às águas de BH.

\section{Categorias}

26 As porcentagens se referem ao total das práticas que apresentaram resultados negativos e não ao total de práticas avaliadas. Educação em Revista| Belo Horizonte|v.36|e217885|2020 


\begin{tabular}{|c|l|}
\hline $\begin{array}{c}\text { Compreensão } \\
\text { teórica }\end{array}$ & $\begin{array}{l}\text { - Contextualizar e articular os conhecimentos teóricos às situações práticas; } \\
\text { - Tratar diferentes assuntos; } \\
\text { - Aprimorar os assuntos tratados. }\end{array}$ \\
\hline \multirow{3}{*}{ Pedagógico } & $\begin{array}{l}\text { - Promover atividades de EA que permitam abranger a prática de pesquisa ou } \\
\text { que sejanejadas de forma intencional; }\end{array}$ \\
& $\begin{array}{l}\text { - Acompanhar e avaliar os resultados utilizando instrumentos adequados; } \\
\text { - O roteiro de atividades e conteúdos trabalhados na EA devem estar alinhados } \\
\text { ao currículo da aprendizagem escolar; } \\
\text { - Promover práticas de EA que tenham continuidade ao longo do tempo. }\end{array}$ \\
\hline Coletividade & - Articulação maior entre os participantes e a comunidade local. \\
\hline
\end{tabular}

Fonte: da pesquisa.

Dentre as práticas de EA avaliadas, em apenas seis (30\%) apresentaram-se sugestões para o seu aperfeiçoamento. Já entre as que apresentaram resultados negativos, em cinco (42\%) apresentaramse sugestões. E ainda, uma (5\%) não apresentou resultados negativos, porém apresentou sugestões de aperfeiçoamento. As sugestões referiram-se a propostas pedagógicas com três (43\%); relativas à coletividade e à compreensão teórica duas (29\%) práticas cada uma (Figura 26).

Figura 26 - Sugestões apresentadas pelas práticas de EA.

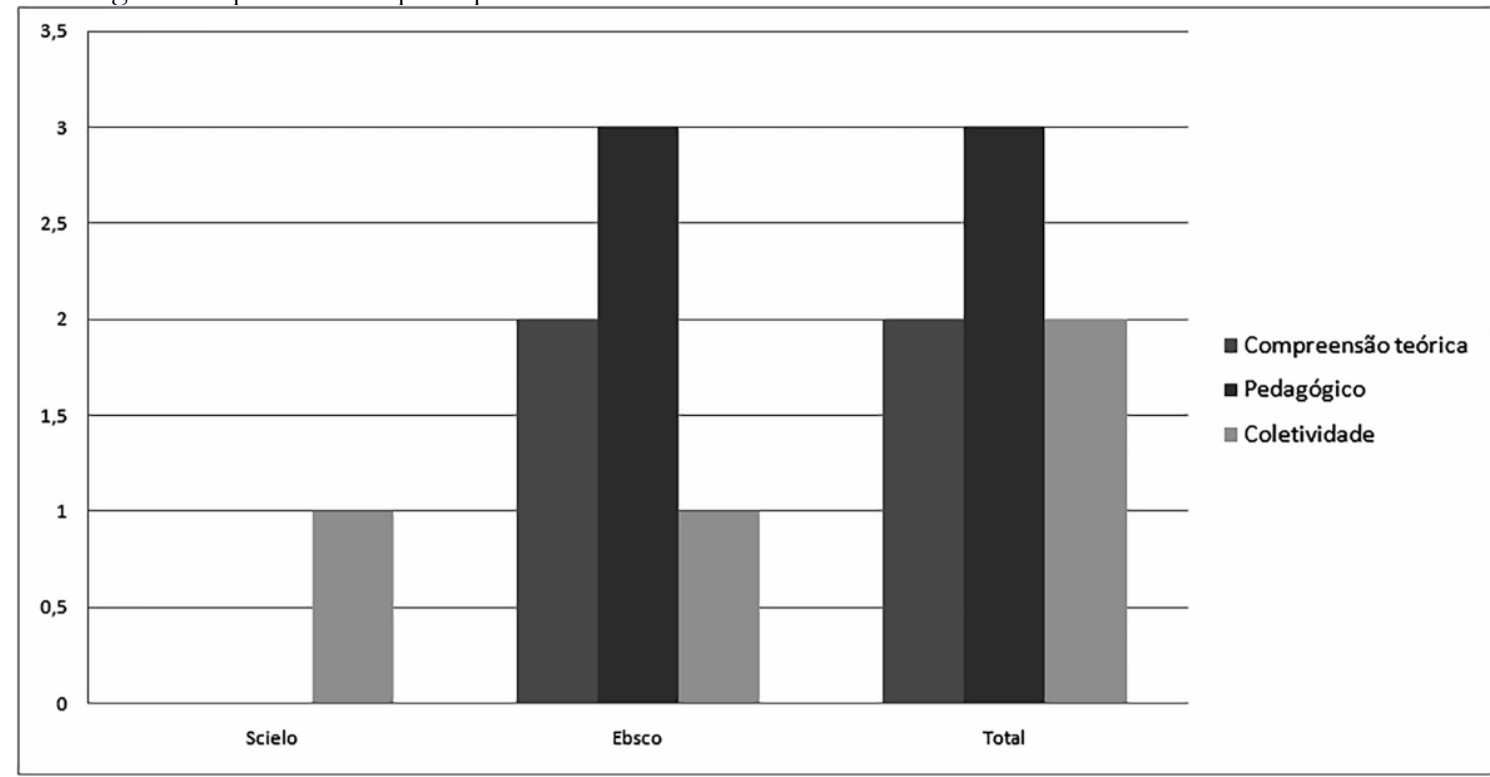

Fonte: da pesquisa.

Poucas foram as práticas que apresentaram sugestões para o seu aprimoramento, sendo que nem todas as que apresentaram resultados negativos propuseram alternativas para contorná-los.

Dentre as sugestões, as que obtiveram destaque foram as relacionadas aos aspectos pedagógicos, que são aquelas que permitem indicar perspectivas para o aprimoramento e avaliação das atividades desenvolvidas. Nesse sentido, percebe-se uma preocupação por parte dos pesquisadores em repensar e aperfeiçoar as práticas.

\section{Bases teóricas da pesquisa}

Quanto às bases teóricas que os artigos se basearam identificam-se um total de 377 obras referenciadas. Entre elas $313(83 \%)$ apresentaram o primeiro autor apenas em uma obra e 64 (17\%) apresentaram o primeiro autor repetido na lista de bibliografia, pertencente a uma mesma ou em diferentes obras.

Os primeiros autores (de cada obra) que se repetiram nos artigos analisados podem ser visualizados na tabela 1 . 
Tabela 1 - Primeiro autor e suas repetições na lista de bibliografias.

\begin{tabular}{|l|c|}
\hline \multicolumn{1}{|c|}{ Primeiro autor } & $\begin{array}{c}\text { Quantidade de } \\
\text { repetições }\end{array}$ \\
\hline Brasil & 15 \\
\hline Freire; e Medeiros. & 6 \\
\hline Chawla; Halldén; Hynek; Loureiro; Mezirow. & 5 \\
\hline $\begin{array}{l}\text { Bodzin; Callisto; Hungerford; Machado; National Research Council; Tozoni-Reis; } \\
\text { e Tundisi. }\end{array}$ & 3 \\
\hline $\begin{array}{l}\text { Deleuze; Driver; Fortner; Gruenewald; Kentucky Division Of Water; Ministry Of } \\
\text { The Environment; North American Association For Environmental Education; }\end{array}$ & 3 \\
Sobel; Thiollent; e United Nations (Un). & \\
\hline $\begin{array}{l}\text { Ballantyne; Bogner; Brehm; Carta De Belgrado; Castro; Clark; Cockerill; Demo; } \\
\text { Dias; Diduck; Falk; González-Gaudiano; Heimlich; Institute For Public Policy } \\
\text { (IPP); Jacobi; Keen; Leeming; Lehigh Earth Observatory; Linsley; Lucatto; } \\
\text { Mahler; Marcinkowski; Mcdonald; Meichtry; Mittermeier; National } \\
\begin{array}{l}\text { Environmental Education Training Foundation; Oliveira; Organização Das } \\
\text { Nações Unidas; Orion; Orr; Roth; Saito; Santos; Simmons; Sinclair; Smith; U.S. } \\
\text { Environmental Protection Agency; Unesco; e Volunteer }\end{array}\end{array}$ \\
\hline
\end{tabular}

Fonte: da pesquisa.

Observa-se que a base teórica sobre a qual as práticas de EA avaliadas está assentada é bastante diversificada e uma pequena quantidade de autores se repetem.

Entre os autores citados têm-se pesquisadores de diversas áreas, documentos oficiais de instituições públicas e de órgãos internacionais, o que demonstra uma preocupação em estruturar as práticas de EA voltada a diversas áreas, incluindo uma base teórica rica, levando em conta os documentos norteadores.

\section{CONSIDERAÇÕES FINAIS}

Considera-se que foram desenvolvidas poucas práticas de EA voltada às águas de $\mathrm{BH}$ após a Rio/92 até 2016, como a coleta aponta. Verificou-se, ainda, uma demora significativa na publicação de artigos nessa área após o evento. A análise mostra características gerais das práticas de EA e uma diversidade de aspectos, com polarização de alguns e concentração de outros.

Existe uma polarização na origem espacial dessas práticas, sendo que elas não se desenvolveram igualmente nos continentes americano e europeu. Constatou-se uma preocupação significativa dos pesquisadores americanos em desenvolver práticas de EA voltadas às águas de $\mathrm{BH}$. $\mathrm{A}$ origem institucional dos autores está concentrada em apenas um tipo de entidade e existe pouca articulação entre entidades. Além disso, os autores concentram-se, em sua maioria, em uma área do conhecimento e o conjunto de autores tem a mesma formação.

Nesse contexto, observa-se que são necessárias estratégias para incluir e articular autores de diferentes entidades e diversas áreas do conhecimento nas práticas de EA, a fim de propiciar a construção de propostas, variadas e embasadas na interdisciplinaridade. Assim, será possível favorecer o aprimoramento da EA voltada às águas de $\mathrm{BH}$.

No entanto, os artigos demonstraram abranger uma diversidade de autores na construção das propostas, assim como de áreas de conhecimento a qual pertencem; de periódicos em sua publicação e das áreas de conhecimento a qual estão vinculados, e uma extensa bibliografia na construção das práticas de EA. Isso permite inferir que as práticas estão alicerçadas em um universo teórico rico.

No tocante as características específicas das práticas de EA, verificou-se que públicos variados são envolvidos, assim como diferentes tipos de EA desenvolvidos. No entanto, existe a preponderância de atividades voltadas a EA formal direcionada ao público jovem, pouco incluindo-se a população adulta e atividades de EA não-formal. Além disso, não se oportuniza a articulação dos diversos públicos e diferentes tipos de EA na mesma prática, o que pode tornar as propostas mais desafiadoras e 
inovadoras, devido à troca de ideias, conhecimentos e experiências que possibilitaria. Nesse tocante, Loureiro (2002) salienta que a EA deve associar atividades de educação escolar com a atuação comunitária, a fim de que se possa promover uma compreensão coletiva da problemática ambiental em escala local, regional e global.

Os objetivos, os métodos e os resultados obtidos nas práticas de EA encontram-se centrados na compreensão teórica das questões ambientais, porém observa-se a inclusão da discussão da realidade local dos atores envolvidos. Verificou-se que os caminhos a serem trilhados para o aprimoramento da $\mathrm{EA}$ voltada às águas de $\mathrm{BH}$ requerem: aprofundar e desenvolver outros conhecimentos e habilidades na efetivação das práticas de EA; incentivar os atores sociais a participar de todas as etapas da estruturação da pesquisa; mobilizar de forma significativa os participantes, assim como, a sociedade para o trato da questão ambiental voltada às águas de $\mathrm{BH}$, gerando uma continuidade temporal e espacial das práticas de EA; e discutir, propor e implementar, de maneira coletiva, ações que possam gerar mudanças efetivas na realidade local.

As estratégias pedagógicas utilizadas nas atividades de EA voltadas às águas de $\mathrm{BH}$ utilizam diversas atividades tradicionais, contudo empregam também formas de interação dinâmicas e inovadoras.

Enfim, as práticas de EA são compostas por características tradicionais e concentram o seu desenvolvimento em algumas áreas, mas mostram-se abertas a possibilidades criativas para a proteção das águas em BHs.

Os resultados obtidos na presente avaliação possuem aproximações com outro estudo empreendido a partir de pesquisas provenientes da Plataforma de Periódicos da CAPES (MEIER, MAZZARINO, s/d, b). Essas características revelam que são poucas as pesquisas que envolvem a temática da EA em bacias hidrográficas, que em sua maioria foram desenvolvidas no continente americano e com autores que se agrupam em torno de uma mesma instituição e segmento de conhecimento. A realidade local foi tratada nas atividades de EA, estando inter-relacionadas com as vivências dos envolvidos, porém estiveram voltadas, em sua maioria, a atividades informativas e teóricas. A base que sustenta as pesquisas é múltipla, envolve diferentes autores, base bibliográfica, públicos nas práticas, tipos de EA, atividades pedagógicas que articulam o tradicional e o inovador, o que por sua vez agrega diversidade e qualidade ao conjunto das práticas de EA.

Os estudos que foram comparados também apontam distinções quanto o tipo de EA que obteve ênfase, sendo entre os estudos do Periódicos da CAPES o não-formal e nos provenientes das bases de dados da DOAJ, SCIELO e EBSCO o formal.

\section{AGRADECIMENTO}

À Coordenação de Aperfeiçoamento de Pessoal de Nível Superior pela concessão de bolsa do Programa Nacional de Pós-doutorado (PNPD/CAPES) à primeira autora.

\section{REFERÊNCIAS}

BERGMANN, M.; PEDROZO, C. S. Explorando a bacia hidrográfica na escola: contribuições à Educação Ambiental. Ciência \& Educação, v. 14, n. 3, p. 537-553, 2008.

BICUDO, M. A. V. Meta-análise: seu significado para a pesquisa qualitativa. Revemat, v. 9, Ed. Temática, jun., p. 7-20, 2014. https://periodicos.ufsc.br/index.php/revemat/article/viewFile/1981-1322.2014v9nespp7/27377.

Acesso em: 09 dez. 2017.

BODZIN, A. M. Integrating Instructional Technologies in a Local Watershed Investigation With Urban Elementary Learners. The journal of environmental education, v. 39, n. 2, p. 47-57, 2008.

BRASIL. Lei n. 9.433, de 8 de janeiro de 1997. Institui a Política Nacional de Recursos Hídricos. Disponível em: http://www2.planalto.gov.br/. Acesso em: 20 dez. 2017. 
CALLISTO, M. et al. Rapid ecological assessment of benthic indicators of water quality: a successful capacity-building experience for Brazilian postgraduate students in ecology. Brazilian Journal of Biology, v. 71, n. 4, p. 937-947, 2011.

CARVALHO, I. C. M. Educação ambiental: a formação do sujeito ecológico. São Paulo: Cortez, 2008.

CASTRO, A. A. Revisão Sistemática e Meta-Análise. Metodologia.org, 10 maio 2001. Disponível em: http://metodologia.org/wp-content/uploads/2010/08/meta1.PDF. Acesso em: 09 dez. 2017.

CIÊNCIA \& EDUCAÇÃO. Disponível em: http://www.scielo.br/scielo.php?script=sci serial\&pid=1516-7313\&lng=es\&nrm=iso. Acesso em: 10 jan. 2018.

CONSELHO NACIONAL DE DESENVOLVIMENTO CIENTÍFICO E TECNOLÓGICO CNPq. 2018. Disponível em: http://www.cnpq.br/documents/10157/186158/Tabelade AreasdoConhecimento.pdf. Acesso em: 20 jan. 2018.

COCKERILL, K. Communicating How Water Works: Results From a Community Water Education Program. The journal of environmental education, n. 41, v. 3, p. 151-164, 2010.

COLABORAÇÃO COCHRANE. Quem somos. Colaboração Cochrane, 2018a. Disponível em: https://www.cochrane.org/pt/2017/about-us. Acesso em: 28 julho 2018.

COLABORAÇÃO COCHRANE. Nossa visão, missão e princípios. Colaboração Cochrane, 2018b. Disponível em: https://www.cochrane.org/pt/2017/about-us/our-vision-mission-and-principles. Acesso em: 28 julho 2018.

DANN, S. L.; SCHROEDER, B. Developing Great Lakes Literacy and Stewardship through a Nonformal Science Education Camp. Journal of Contemporary Water Research \& Education, n. 156, dez., p. 21-36, 2015.

DIAS, L. S.; MARQUES, M. D.; DIAS, L. S. Educação, Educação Ambiental, percepção ambiental e educomunicação. In: DIAS, L. S.; LEAL, A. C.; CARPI JUNIOR, S. Educação Ambiental: conceitos, metodologias e práticas. Tupã, São Paulo: ANAP, 2016. p.12-44.

GADOT'TI, M. Pedagogia da Terra. São Paulo: Peirópolis, 2000.

GAMA, S. V. G.; CARVALHO, D. T.; CARVALHO JÚNIOR, R. P. de. Geografia, planejamento ambiental e educação ambiental: entre os parâmetros legais e as práticas reais. Geo UERJ, ano 14, n. 23, v. 2, set. 2012, p. 524-551.

HYDE, R. A.; KARNEY, B. W. Thinking like a fish: curriculum enhancements for increased environmental learning in hydraulics and hydrology. Journal of Hydraulic Engineering, v. 125, n. 11, p. $1114-1117,1999$.

LIMA, G. F. da C. Crise ambiental, educação e cidadania: os desafios da sustentabilidade emancipatória. In: LOUREIRO, C. F. B.; LAYRARGUES, P. P.; CASTRO, R. S. de (orgs). Educação ambiental: repensando o espaço da cidadania. São Paulo: Cortez, 2002, p. 109-141. 
LOUREIRO, C. F. B. Educação ambiental e movimentos sociais na construção da cidadania ecológica e planetária. In: LOUREIRO, C. F. B.; LAYRARGUES, P. P.; CASTRO, R. S. de (orgs). Educação ambiental: repensando o espaço da cidadania. São Paulo: Cortez, 2002, p. 69-107.

LUCATTO, L. G.; TALAMONI, J. L. B. A construção coletiva interdisciplinar em educação ambiental no ensino médio: a microbacia hidrográfica do Ribeirão dos Peixes como tema gerador. Ciência \& Educação, v. 13, n. 3, p. 389-398, 2007.

MEICHTRY, Y.; SMITH, J. The Impact of a Place-Based Professional Development Program on Teachers' Confidence, Attitudes, and Classroom Practices. The Journal of Environmental Education, v. 38, n. 2, p. 15-34, 2007.

MEIER, M. A.; MAZZARINO, J. Educação Ambiental, água e bacia hidrográfica: uma análise sistemática nas bases de dados EBSCO, DOAJ e SCIELO. Não publicado (a).

MEIER, M. A.; MAZZARINO, J. Propostas de Educação Ambiental direcionadas às águas em bacia hidrográfica: uma revisão sistemática no Portal de Periódicos da CAPES. Não publicado (b).

MOLINA, Y. Programa de educación ambiental para la cuenca del río Mucujún: una ventana de extensión universitaria. Educere, v. 10, n. 34, jul/set, p. 471-481, 2006.

MUÑOZ, H. R.(org.). Interfaces da Gestão de Recursos Hídricos: desafios das águas de 1997. 2 ed. Brasília: Secretaria de Recursos Hídricos, 2000.

OBARA, A. T. et al. Environmental education for sustainable management of the basins of the rivers Pirapó, Paranapanema III and Parapanema IV. Brazilian Journal of Biology, v. 75, n. 4, p. 137-147, 2015.

ÖSTERLIND, K.; HALLDÉN, O. Linking Theory to Practice: A Case Study of Pupils' Course Work on Freshwater Pollution. International Research in Geographical and Environmental Education, v. 16, n. 1, p. 73-89, 2007.

PALMEIRO, V.; GIOPPO, C. Ui, que nojo! Tem mais é que fechar esse valetão! Um estudo com o conceito deleuzeano de devir. Educar em Revista, n. 40, abr/jun, p. 85-106, 2011.

PELICIONI, M. C. F.; PHILIPPI JR. A. Bases políticas, conceituais, filosóficas e ideológicas da Educação Ambiental. In: PHILIPPI JR. A.; PELICIONI, M. C. F. Educação Ambiental e sustentabilidade. Barueri, SP: Manole, 2014, p. 3-12.

PETRIKOVA, G. A Drainage Basin in Environmental and Geographical Education: A Case Study of the Kretinka Drainage Basin. International Research in Geographical and Environmental Education, v. 12, n. 2, p. 91-105, 2003.

PICCOLI, A. S. et al. A Educação Ambiental como estratégia de mobilização social para o enfrentamento da escassez de água. Ciência \& Saúde Coletiva, v. 21, n. 3, p. 797-808, 2016.

RIBEIRO, W. C. Geografia Política da água. São Paulo: Annablume, 2008. 162 p.

RODRIGUES, C. A abordagem processual nos estudos da tradução: Uma análise metaanálise qualitativa. Cadernos de Tradução (UFSC), Florianópolis, v. 10, n. 2, p. 23-59, 2002. Disponível em: http://www.periodicos.ufsc.br/index.php/traducao/article/viewPDFInterstitial/6143/5701. Acesso em: 03 dez. 2017. 
ROMÁN, B.; NAHUELHUAL, L.; MOREY, F. Programa de educación ambiental para comités de agua potable rural en el sur de Chile. Educere, v. 13, n. 45, abr/jun, p. 523-529, 2009.

RUFFINO, P. H. P.; SANTOS, S. A. dos. Utilização do conceito de bacia hidrográfica para capacitação de educadores. In: SCHIAVET'TI, A. CAMARGO, A. F. M. Conceitos de bacias hidrográficas: teorias e aplicações. Ilhéus: Editus, 2002, p. 111-123.

SANTOS, E. L. F.; MEDEIROS, H. Q.; SILVA, C. J. Educação ambiental e diálogo de saberes em região de nascentes do Pantanal: Reserva do Cabaçal, Mato Grosso, Brasil. Ciência \& Educação, v. 19, n. 4, p. 879-896, 2013.

SHEPARDSON, D. P. et al. The Impact of a Professional Development Program on Teachers' Understandings about Watersheds, Water Quality, and Stream Monitoring. The Journal of Environmental Education, v. 33, n. 3, p. 34-40, 2002.

SILVEIRA, G. T. R. Educação Ambiental como Instrumento de Gestão de Recursos Hídricos: Uma Proposta de Intervenção. In: IX Congresso da Associação Brasileira de Estudos do Quaternário. II Congresso do Quaternário de Países de Línguas Ibéricas. II Congresso sobre Planejamento e Gestão da Zona Costeira dos Países de Expressão Portuguesa, 2003. Recife. Anais... Recife, 2003. Disponível em: http://www.abequa.org.br/trabalhos/dinamica costeira 287.pdf. Acesso em: 10 jan. 2018.

SIMS, L.; SINCLAIR, A. J. Learning through participatory resource management programs: case studies from Costa Rica. Adult Education Quarterly, v. 58, n. 2, fev., p. 151-168, 2008.

THE JOURNAL OF ENVIRONMENTAL EDUCATION. Disponível em: http://www.tandfonline.com/action/journalInformation? show=aimsScope\&journalCode=vjee20.

Acesso em: 10 jan. 2018.

THIOLLENT, M. Metodologia da pesquisa-ação. 18. ed. São Paulo: Cortez, 2011.

TUNDISI, J. G.; BRAGA, B. REBOUÇAS, A. C. Os recursos hídricos e o futuro: síntese. In: REBOUÇAS, A. da C.; BRAGA, B.; TUNDISI, J. G. Águas doces no Brasil: Capital ecológico, uso e conservação. 3 ed. São Paulo: Escrituras Editora, 2006, p. 739-749.

VIEZZER, M. L. Pesquisa-ação-participante (PAP): Origens e avanços. In: FERRARO JÚNIOR, L. A. Encontros e caminhos: formação de educadoras(es) ambientais e coletivos educadores. Brasília: MMA, Diretoria de Educação Ambiental, 2005, p. 279-294.

WATSON, S. A. Reflections on an Environmental Education Summer Program in Appalachian Ohio. Journal of Appalachian Studies, v. 20, n. 1, p. 68-80, 2014.

Submetido: 20/03/2019

Aprovado: 04/08/2020 